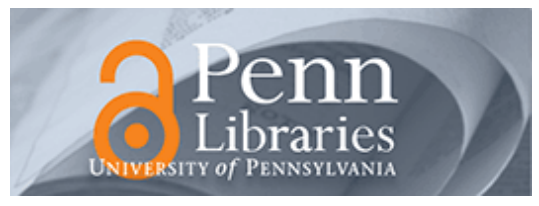

University of Pennsylvania

ScholarlyCommons

Accounting Papers

Wharton Faculty Research

9-2007

\title{
Biases in Multi-Year Management Financial Forecasts: Evidence From Private Venture-Backed U.S. Companies
}

Christopher S. Armstrong

University of Pennsylvania

Antonio Dávila

George Foster

John R. M. Hand

Follow this and additional works at: https://repository.upenn.edu/accounting_papers

Part of the Accounting Commons, and the Finance and Financial Management Commons

\section{Recommended Citation}

Armstrong, C. S., Dávila, A., Foster, G., \& Hand, J. M. (2007). Biases in Multi-Year Management Financial Forecasts: Evidence From Private Venture-Backed U.S. Companies. Review of Accounting Studies, 12 (2), 183-215. http://dx.doi.org/10.1007/s11142-007-9033-4

This paper is posted at ScholarlyCommons. https://repository.upenn.edu/accounting_papers/87

For more information, please contact repository@pobox.upenn.edu. 


\title{
Biases in Multi-Year Management Financial Forecasts: Evidence From Private Venture-Backed U.S. Companies
}

\author{
Abstract \\ firms' assets.

\section{Keywords} \\ management forecasts, optimism, strategic biases, venture capital \\ Disciplines \\ Accounting | Finance and Financial Management
}

This paper studies the properties and determinants of managers' multi-year financial forecasts. Using one- to five-year-ahead forecasts reported by private venture-backed firms, we ask whether, by how much, and why biases in managers' forecasts of revenues, expenses and profits depend on the forecasting horizon and the verifiability of assets. We find that profitability forecasts contain a strategic component, in that [1] one-year-ahead revenue (expense) forecasts are slightly and asymmetrically pessimistic (optimistic), while five-year-ahead forecasts are hugely and asymmetrically optimistic (pessimistic); and [2] biases in revenue and expense forecasts are larger, the harder to verify or more intangible-intensive are 


\section{Biases in multi-year management financial forecasts: Evidence from private venture-backed U.S. companies}

Article in Review of Accounting Studies · June 2007

Impact Factor: $2.02 \cdot$ DOI: 10.1007/s11142-007-9033-4

CITATIONS

4

4 authors, including:

Antonio Davila

Universidad de Navarra

43 PUBLICATIONS 1,697 CITATIONS

SEE PROFILE
READS

25

George Foster

Stanford University

30 PUBLICATIONS 1,327 CITATIONS

SEE PROFILE 


\title{
Biases in Multi-Year Management Financial Forecasts: Evidence from Private Venture-Backed U.S. Companies
}

\author{
Christopher S. Armstrong ${ }^{\$}$, Antonio Dávila ${ }^{€}$, George Foster ${ }^{\$}$, John R. M. Hand ${ }^{£}$
}

\begin{abstract}
This paper studies the properties and determinants of managers' multi-year financial forecasts. We ask whether, by how much, and why biases in managers' forecasts of revenues, expenses and profits depend on the forecasting horizon and the verifiability of firms' assets. Since public companies rarely divulge their internal multi-year financial projections to outsiders, we use the one- to five-year-ahead management forecasts reported by private venture-backed firms. We also introduce a new method of measuring financial forecast bias that compares forecasts to historically-grounded conditional projections, rather than to ex-post actuals. We find that on average, managers' forecasts of firm profitability and revenues are optimistic, especially as the forecast horizon increases to five-years-ahead. Managers' expense forecasts become more pessimistic as the forecast horizon rises, most likely arising from the need on managers' part to respect 'reasonable' relations between revenues and expenses. We conclude that profitability forecasts contain a strategic component, in that: [1] One-year-ahead revenue (expense) forecasts are slightly and asymmetrically pessimistic (optimistic), and five-year-ahead forecasts are hugely and asymmetrically optimistic (pessimistic); and [2] Biases in revenue and expense forecasts are larger the harder to verify or more intangible-intensive are firms' assets.
\end{abstract}

JEL classifications: G24, M13, M41.

Keywords: $\quad$ Management forecasts; Optimism; Strategic biases; Venture capital.

$1^{\text {st }}$ draft: October 17, 2005

This version: November 6, 2006

${ }^{\$}$ Graduate School of Business, Stanford University; ${ }^{€}$ IESE Business School, Universidad de Navarra; and ${ }^{\mathfrak{E}}$ Kenan-Flagler Business School, UNC Chapel Hill. Hand is the corresponding author. We are most grateful to John Gabbert of VentureOne for providing us with access to VentureOne's financial forecast database, and to an anonymous referee, Liz Demers (discussant), R. Barniv, R. Bloomfield, M. Bradshaw, M. Kimbrough, S.P. Kothari, G. Miller, E. Reidl, M. Soliman, M. Venkatachalam and seminar participants at Harvard Business School, Kent State University, and the 2006 Review of Accounting Studies Conference for valuable comments and suggestions. Armstrong, Dávila and Foster acknowledge support from the Center for Entrepreneurial Studies at Stanford University. Hand thanks the Edward O'Herron, Jr. Fund at UNC Chapel Hill for its financial support. 


\section{Introduction and Summary}

Managers create and use multi-year financial forecasts for a wide variety of operating, investing, financing, accounting, budgeting, control, governance, compensation, and valuation purposes. Developing multi-year financial forecasts is therefore a highly pervasive and important managerial task. In this paper, we explore the properties and determinants of managers' multi-year financial forecasts. We particularly ask whether, by how much, and why any biases in managers' multi-year forecasts of revenues, expenses and profitability depend on the length of the forecasting horizon, and the verifiability of forecasting firms' economic assets.

To date, the rich extant literature on management forecasts has almost exclusively focused on short-term forecasts. This is because despite safe-harbor-type provisions, publicly traded companies rarely inform outsiders of their internal expectations more than one or two years into the future. We seek to tackle this problem by using financial forecasts that are disclosed voluntarily by private U.S. firms to VentureOne, a leading provider of data to venture capital funds. ${ }^{1}$ While this markedly limits the generalizability of our results, and creates several methodological risks, our study provides the first large-sample evidence as to the properties of managers' multi-year, long-term revenue, expense and net income forecasts. As such, we add to both the well-established literature that has studied financial forecasts made by management (e.g., Patell, 1976; Penman, 1980; Waymire, 1984; Kasznik and Lev, 1995; Miller, 2002; Hutton, Miller and Skinner, 2003; Rogers and Stocken, 2005; Wasley and Wu, 2006), and the emerging literature on management earnings guidance (Brown and Higgins, 2005; Hutton, 2005).

We also introduce an alternative method for measuring the biases in financial forecasts. In contrast to prior work, our method centers on comparing managers' forecasts with what would be expected given the historical performance of firms as a whole, as well as conditioning on key characteristics of the firm itself. We refer to these benchmark forecasts as historically-grounded conditional projections, or 'historical projections' for short. We use the historical projection approach because VentureOne's database does not report ex post actuals that can be matched against managers' forecasts. The approach was first used in labor economics to investigate issues of alleged pay discrimination against minorities (Blinder, 1973; Oaxaca, 1973). Although

\footnotetext{
${ }^{1}$ We recognize that the paucity of management forecasts beyond one or two years into the future is not limited to financial forecasts. As such, the fact that publicly traded firms voluntarily provide only short-horizon forecasts affects literatures other than accounting-e.g., economics, marketing and operations.
} 
our application of the method places high inferential weight on accurately modeling firms' historical financial performance, the method has particular promise for evaluating the degree of bias in long-term forecasts made by young companies. This is because requiring there be longterm ex post actual results to compare against long-term forecasts would for young firms substantially reduce the number of available observations. Also, young companies such as those financed by venture capital face big going-concern risks, or the possibility of exit as a trade sale, and therefore and may well not survive as an independent company five years into the future.

We analyze the large set of management financial forecast errors generated through the use of the historically-grounded conditional projection method in two main ways.

First, we document whether and how the signs and magnitudes of management forecast biases vary as a function of the length of the forecasting horizon. Prior work in entrepreneurship has argued theoretically, and concluded empirically, that entrepreneurs are hard-wired to be highly optimistic and risk seeking (e.g., Simon, Houghton and Aquino, 1999; Rigotti, Ryan and Vaithianathan, 2003; Landier and Thesmar, 2004; Puri and Robinson, 2005; Lowe and Ziedonis, 2006). This leads us to make the introductory prediction that if the managers making the forecasts provided by firms to VentureOne are similarly driven by hard-wired behaviorally-based optimism, and only by hard-wired behaviorally-based optimism, then those managers' forecasts of revenues, expenses and profitability will be optimistic at all forecasting horizons, equally present for all kinds of firms, and increase as the length of the forecasting horizon increases.

Empirically, we do find that for the pooled sample of firms, managers' profitability forecasts are significantly and increasingly optimistic as the forecasting horizon rises from oneto five-years-ahead. Managers make one-year-ahead forecasts of profitability (defined as managers' forecasts of net income less historically projected net income, scaled by historically projected revenues) that are on average 35\% too high. This bias rises monotonically such that three- and five-year-ahead forecasts of profitability are $67 \%$ and $122 \%$ too high, respectively.

However, we do not find that optimism is invariably present in the revenue and expense components of managers' profit forecasts. Specifically, we show that one-year-ahead revenue forecasts are on average reliably understated (pessimistic) by $11 \%$, and three- through five-yearahead expense forecasts are reliably overstated (pessimistic) by $25 \%, 41 \%$ and $80 \%$, respectively. Such pessimism is inconsistent with managers making solely optimistic forecasts. 
The second type of analysis that we undertake is to investigate whether and why biases in managers' multi-year revenue, expense or profitability forecasts reflect strategic behavior. Our motivations are threefold. First, we seek to determine whether the horizon-specific pessimism in revenues and expenses discussed above are consistent with strategic forecasting by managers. We conclude that they are. For example, although one-year-ahead revenue forecasts are on average reliably pessimistic by $11 \%$, one-year-ahead expense forecasts are reliably optimistic by more-28\% - leading to one-year-ahead profitability forecasts that are upward biased by 35\%. This could be consistent with managers strategically understating their true expectations of shortterm revenues and expenses so as to present venture investors with a favorable view of their current cash burn (via optimistic short-term expense forecasts) but also emphasize their need for new capital that will create higher revenues (via pessimistic short-term revenue forecasts).

Our second motivation for considering strategic motives in managers' forecasts is that managers of private venture-backed firms face a very strong incentive to overstate their forecasts of long-term future net income. This is because the higher is the firm's true long-term net income, the more likely is the forecasting firm to secure its next round of venture financing (without which, the firm may well go out of business). In this sense, our paper is related to research that has used public company data to study the incentives that managers face to provide voluntary disclosures to access the capital markets and lower the firm's cost of capital (Frankel, McNichols and Wilson, 1995; Healy, Hutton and Palepu, 1999; Lang and Lundholm, 2000).

We conclude that our evidence on long-term forecast biases are consistent with this view, because although three- through five-year-ahead expense forecasts are on average reliably pessimistic, three- through five-year-ahead revenue forecasts are even more optimistic, leading to one-year-ahead profitability forecasts that are optimistically biased by between $67 \%$ and $122 \%$. We conjecture that managers realize that although their predictions of how large future revenues will be is hard for venture investors to disprove, the relations between future revenues and future expenses are somewhat constrained. That is, managers realize that venture investors will (and do) pore over their pro-forma spreadsheets with a view to making sure that conditional on managers' long-term revenue projections, long-term expense projections “exhibit reasonable internal consistency.” We conjecture that this revenue-conditional constraint is what leads managers to make what appear to be pessimistic forecasts about their long-term future expenses. 
Finally, we hypothesize that managers of venture-backed private companies are more likely to impart strategic bias to their financial forecasts the harder (costlier) it is for venture funds to verify the existence and magnitude of the firms' economic assets. Our reasoning draws on the insights of Rogers and Stocken (2005), who establish that managers of public firms are more likely to bias their forecasts when it is more difficult for investors to detect that they have misrepresented their information. In our setting, we propose that the cost of verification is larger the more intangible-intensive is a firm, since intangible assets consist of $R \& D$, patents, trademarks, copyrights, brand names, intellectual capital, innovative ideas and processes, all of which typically lack physical substance or liquid secondary markets, thereby making them hard to both audit and value (Lev, 2001). Lacking direct measures on R\&D, patents, etc., we use the industry sector that VentureOne classifies firms into as a proxy for intangible intensity.

We find evidence consistent with the verification hypothesis. For example, the forecast bias in profitability for healthcare/biotechnology firms (hard-to-verify assets) is two and eight times larger than that for retail firms (easy-to-verify assets). Moreover, consistent with the idea that revenue forecasts are harder for venture investors to verify than expense forecasts, particularly when the underlying economic assets are hard-to-verify, biotechnology firms’ oneand five-year-ahead revenue forecasts are $49 \%$ and 305\% optimistic, but retail firms' one- and five-year-ahead revenue forecasts are $41 \%$ pessimistic and only $3 \%$ optimistic, respectively.

Overall, our paper contributes to three literatures. With regard to the management forecasting literature, we shed light on the properties of longer-term forecasts and forecast biases, not only for net income but also its revenue and expense components. Our results suggest that not only are biases widespread in the financial forecasts made by managers of private venture-backed firms, but they appear to be strategic. Specifically, we find that the magnitude and type of strategic bias that managers impart to their forecasts depends on both the forecast horizon and the verifiability of firms’ assets (Rogers and Stocken, 2005).

With regard to the forecast evaluation literature, we import and apply from labor economics an alternative method of measuring financial forecast bias. In this method, forecasts are compared to historically-grounded conditional projections, rather than to ex-post actual results. As with any statistical or quasi-experimental tool, this method has strengths and weaknesses, but its robustness in our setting suggests that it may be a useful addition to conventional approaches to comparing financial forecasts with actuals. For example, it may help 
researchers to measure and understand biases in equity analysts' long-term revenue and earnings growth forecasts (Dechow and Sloan, 1997; Chan, Karceski and Lakonishok, 2003).

Finally, our study adds to the small but growing literature in accounting that focuses on the economics of young companies, particularly those backed by venture capital (Dávila, Foster and Gupta, 2003; Beuselinck, Deloof and Manigart, 2005; Dávila, 2005; Hand, 2005, 2006; Armstrong, Dávila and Foster, 2006; and Dávila and Foster, 2005, 2006). Venture-backed firms are becoming increasingly important in the modern economy (Gompers and Lerner, 2000; National Venture Capital Association, 2004): Microsoft, Genentech, Apple Computer and Google among many others were once small startups whose ultra-rapid growth has significantly affected the U.S. and worldwide economies. Among the contributions our paper makes to this emerging literature is that we systematically describe how young firms' revenues, expenses and net income evolve over time, and the "hockey stick” aspects to managers' financial forecasts. We also provide venture capital investors with measures of the size of the "haircuts" that they either do or might need to apply to managers' forecasts at different horizons, such as those contained in business plans submitted to them by firms seeking high-risk capital.

The remainder of the paper proceeds as follows. In section 2, we describe VentureOne's financial forecast database. Section 3 details the empirical methods we employ. Section 4 reports our empirical results; summarizes the results of several tests that assess the robustness of our results, particularly those aimed at assessing the methodological problems and risks inherent in the historical projection method; and points to future work. Section 5 concludes.

\section{Data and Descriptive Statistics}

Our analysis of the multi-year financial forecasts made by managers of private firms utilizes a database built and maintained by VentureOne. VentureOne is a leading venture capital research firm that offers investors, service providers, and entrepreneurs comprehensive, accurate, and timely information on the venture capital industry. VentureOne's products and services are designed to help venture capital firms, corporate investors, investment banks, and accounting and law firms identify private investment opportunities, perform due diligence and evaluate market trends, including benchmarking company valuations and documenting industry preferences.

VentureOne's primary product is VentureSource ${ }^{\mathrm{TM}}$, an online and continuously updated set of venture capital data, including complete business information on investors and venture- 
backed companies, venture financing transactions, valuation information, and key executives and board members. $^{2}$ One of many inputs into VentureSource ${ }^{\mathrm{TM}}$ is VentureOne's financial statement database. This database contains historical and forecasted revenues and net income for a large number of U.S. and European venture-backed firms over (at most) the period 1985-2007.

Most information in the VentureOne's financial statement database comes from the regular contacts that VentureOne makes with venture-backed companies, most often in the form of quarterly emails asking firms to update their VentureOne profile. ${ }^{3}$ Firms benefit from providing VentureOne with their revenue, expense and net income forecasts because they do not have to pay to have their data included and their forecasts are immediately loaded into their company profile maintained in VentureSource ${ }^{\mathrm{TM}}$. This makes it possible for firms to efficiently alert venture capital funds to their projected future business activities and results. The only entities that VentureOne allows (or in all likelihood can afford) to subscribe to VentureSource ${ }^{\mathrm{TM}}$ are venture capital and private equity funds, and strategic corporate investors. These businesses comprise the major potential suppliers of equity capital to young technology startup firms. Other than large corporations with legitimate venture capital subsidiaries, actual or potential competitors to venture-backed startups are not allowed to subscribe to VentureSource ${ }^{\mathrm{TM}}$. As a result, VentureOne acts as an agnostic and independent information conduit between private firms that demand capital and venture and private equity funds that supply it.

The nature of VentureOne's financial statement database is illustrated in figure 1. Two features warrant attention. First, of critical importance to our study is the fact that for each firm in the database, VentureOne reports a single time-series of between zero to 12 years of historical annual revenues and net income followed by between zero and eight years of forecasted revenues or net income. ${ }^{4}$ This means that there is no historical revenue or net income data against which a given firm's forecasts can be compared against actuals, so conventionally defined forecast errors

\footnotetext{
${ }^{2}$ VentureSource ${ }^{\mathrm{TM}}$ covers U.S., European and Israeli startups and investors. It holds data on 21,000 companies and 7,000 investors, over 50,900 transactions and over 131,900 key executives. Research that has used VentureOne data include, among others, Gompers and Lerner (2000), Dávila, Foster and Gupta (2003), Seppä (2003), Cochrane (2005), Dávila and Foster (2005), Hand (2005, 2006), and Gompers, Lerner and Scharfstein (2005).

${ }^{3}$ We acknowledge that the voluntary and self-reported updating by firms of their VentureOne profile may lead to incomplete data records. For example, Kaplan, Sensoy and Strömberg (KSS, 2002) report that VentureOne and Venture Economics exclude roughly 15\% of the financing rounds of 143 actual venture financings obtained by KSS from fourteen venture capital partnerships. However, KSS find that unlike Venture Economics, VentureOne's financing data exhibits no significant bias. The degree to which the incompleteness exhibited by financing data extends to non-financing data of the kind we study is an important issue on which no research has yet been done.

${ }^{4}$ We compute total expenses as the difference between revenues and net income, where both exist.
} 
(viz., actual less forecast) cannot be computed. ${ }^{5}$ We address this limitation by developing an alternative method of estimating the bias in firms’ financial forecasts in section 3.1.

The second notable feature of VentureOne's financial statement database is that there may be selection forces at work regarding which firms do and do not provide forecasts, why they do or do not provide forecasts, and when and why a forecast in the database is or is not updated by overwriting it with the actual financial statement results that subsequently occurred (if there were any, since the firm might have merged or gone out of business). We elaborate on these limitations and our approach to assessing their significance in section 4.4 and appendix A.

Table 1 describes the selection criteria that were applied to VentureOne’s financial statement database so as to obtain a set of firm-year observations that could be used to estimate the biases, if any, in firms' one- through five-year-ahead forecasts of revenue, expense and net income. The strictures imposed were that a firm's founding date, industry classification, and state location had to be available in VentureSource ${ }^{\mathrm{TM}}$; revenue in a given year could not be missing, even if net income was reported; the fiscal year corresponding to a revenue number had to be known and not before 1985 or after 2007; a firm could not be more than 15 years old in the year corresponding to the revenue number; revenues had to be "Actual” or "Forecast", not "Estimated"; and forecasts had to have a horizon of no more than five years ahead. Beyond these criteria, we also excluded a few extreme outliers that were visually identified from scatter plots of revenue against firm age. ${ }^{6}$ In total, these restrictions left 9,276 U.S. firm-years between 1985 and 2007 for which there is either an historical or forecasted revenue figure available. ${ }^{7}$

Table 2 reports descriptive statistics on firm age, industry composition, U.S. states in which firms are headquartered, and the distribution of historical revenues and one- through fiveyear-ahead revenue forecasts relative to the fiscal years they pertain to. Firm age is distributed similarly across historical and forecasted observations (panel A). Firms are concentrated in the industry sectors defined by VentureOne as Information Technology, Healthcare/Biotech and Retail \& Consumer/Business Products/Services. A heavy geographic clustering of firms is seen

\footnotetext{
${ }^{5}$ Although VentureOne regularly updates and therefore overwrites its database, it would in principle be possible to compare forecasts to subsequent forecasts if prior versions of the database were available, for example, one CD per year going back to 1985 . However, we have been informed by VentureOne that they do not keep historical records. ${ }^{6}$ Most extreme outliers were pure data errors. For example, several outliers had firm age information that dramatically understated the true age of the firm, thereby yielding an incorrectly high revenue figure.

${ }^{7}$ The most significant data restriction is the absence of a firm's founding date. Although we include firm age as a key variable in our analysis, repeating the analyses in the study without firm age lead to similar estimates of, and inferences with regard to, the degree and nature of management biases in revenues, expenses and profitability.
} 
in California and to a lesser degree Massachusetts, although a full tabulation reveals that virtually every state in the U.S. is represented at least once (panel B). Finally, while the number of forecasts declines as the forecast horizon increases, even at the five-years-ahead horizon there are 139 forecasts in the database, each of which is made by a different firm (panel C). And although not explicitly shown, almost all firms with, say, a five-year-ahead revenue forecast also have four-, three-, two- and one-year ahead revenue forecasts.

Moving to firms’ actual and forecasted revenues, expenses and net incomes, figure 2 visually displays the medians of these financial variables as a function of firm age. ${ }^{8}$ All variables are expressed in real terms pivoting from the CPI in June 2005. Two aspects warrant attention. First, managers' forecasts of their firms' revenues exceed the revenues historically experienced by firms of the same age. For example, firms that are seven years old are forecasted by their managers to have median real revenue of $\$ 25$ million, whereas the median real revenue of firms seven years old based on historical data is only $\$ 12$ million. The same applies to expenses, although the gap is not quite so pronounced. Second, managers appear highly optimistic about how old their firm will be when it first turns a profit. The median age at which firms historically first turn a profit is 10 years old, but the median age at which firms forecast that they will turn profitable is only four years old.

Table 3 provides another view of managers’ forecasts versus firms’ historical data by reporting as a function of the forecasting horizon the medians and means of revenues, expenses and net income (panel A), the means and key percentiles of firms' annual growth rates in revenue and expense (panels B - C), and net income-to-expense profitability ratios (panel D). ${ }^{9}$ We highlight three aspects of table 3. First, table 3 suggests that managers' revenue forecasts appear to embed far higher annual rates of growth than those justified by historical performance of private venture-backed companies as a group. For example, panel A shows that at the median, managers forecast that one-year-ahead revenues of \$5.3 million will grow to five-year-ahead revenues of $\$ 61.0$ million, an implied annual rate of $84 \%$. But panel B indicates that the median annual growth rate in actual, realized revenues is only 48\%. Moreover, in terms of year-to-year revenue growth rates, managers’ optimism appears to be more severe the shorter is the forecast

\footnotetext{
${ }^{8}$ Unreported results show that means yield qualitatively the same inferences, but are far less amenable to being presented in an easy-to-read visual display because a minority of firms experience huge revenues as they mature, thereby distorting the visual scale onto which all means are reported.

${ }^{9}$ We report net income-to-expense rather than net income-to-revenue ratios to minimize the statistical distortions created by zero revenues or very small revenues.
} 
horizon, peaking at two-years-ahead. ${ }^{10}$ A similar but less extreme pattern is seen for expenses (panel C), although the larger growth rates implicit in managers' forecasts of expenses than suggested by history point to unconditional pessimism, not optimism.

The second observation of note in table 3 is that as judged by net income-to-expense profitability ratios, managers' forecasts point to future profitability substantially above that of the historical reported profitability—or lack thereof—manifested private venture-backed firms as a group. For example, the median historical net income-to-expense profitability ratio is $-34 \%$ (panel D). However, managers' median forecasted net income-to-expense ratio ranges between $-20 \%$ at the one-year-ahead horizon to $21 \%$ at the five-year-ahead horizon. Similar optimism is apparent in the other percentiles, particularly the $10^{\text {th }}$ and $25^{\text {th }} .{ }^{11}$

Third, panel E of table 3 reports the results of regressing two measures of firms' historical profitability on each of the three major industry sectors (Healthcare/Biotech; Information Technology; Retail \& Cons/Bus Prod/Serv), and firm age. The results indicate that historical reported profitability varies substantially across industry. This suggests that it will likely be important to take industry sector into account in developing historically-grounded predictions to compare against managers' financial forecasts. Also, we interpret the rank ordering of historical profitability across the three major industry sectors to be indicative of the relative intensity of intangibles in the economic assets of firms in those industries. This is because the accounting for intangibles such as R\&D and intellectual capital is full and immediate expensing (capitalization of internally generated R\&D is not permitted under GAAP), leading to bigger expenses and therefore seemingly worse reported profitability the more intangible are the firm's economic assets, particularly when the firm is growing rapidly. We exploit this inference in section 4.3 when we analyze the extent to which managers' financial forecast biases depend on asset verifiability, for which we use intangible-intensity as our proxy.

In total, the largely unconditional and therefore preliminary evidence reported in figure 2 and table 3 suggests that managers of young, private venture-backed companies more often than not make forecasts that are higher—sometimes hugely so—-than historically justified norms. In

\footnotetext{
${ }^{10}$ Some very high one- and two-year-ahead forecasted growth rates are in part due to companies that have very low revenues in the denominator of the growth rate calculation.

${ }^{11}$ The dominance of reported losses in our sample echoes the results reported by Armstrong, Dávila and Foster (2006). They report that for a sample of 502 venture-backed companies that went public, the $10^{\text {th }}$ through $70^{\text {th }}$ percentiles of net income is always negative in each of the three years prior to the IPO, the year of the IPO, and the three years immediately following the IPO.
} 
the next section, we introduce to the accounting literature an alternative method of measuring the degree of bias in financial forecasts, and seek to determine whether, by how much, and why biases in our sample of managers' forecasts of revenues, expenses and profitability depend on forecasting horizon and the verifiability of firms’ economic assets.

\section{A New Approach to Measuring Biases in Managers’ Financial Forecasts}

By its construction, VentureOne’s financial statement dataset does not permit us to measure multi-year forecast biases in the conventional way- that is, by comparing forecasts to actuals and then averaging the resulting forecast errors. Instead, we measure forecast bias by comparing managers' forecasts with what would be expected given the historical performance of firms as a whole, and conditioning on key characteristics of the firm itself. We refer to the latter as historically-grounded conditional projections, or historical projections for short. This type of approach is known as the 'residual difference method' in labor economics, where is often used to investigate charges of pay discrimination against minorities (Blinder, 1973; Oaxaca, 1973;

Oaxaca and Ransom, 1994). ${ }^{12}$ The method is not without methodological risks, and we elaborate on these and our approach to assessing their significance in section 4.4 and appendix A.

\subsection{Historical projection method of predicting revenues, expenses and net income}

We illustrate the historical projection approach using revenues. First, for the full set of 6,890 available firm-year actual revenues described in table 2 (panel A) and table 3, we estimate a simple "baseline" revenue model for each of the $k=1$ to 4 industry sectors into which VentureOne classifies firms in its database (Healthcare/Biotech; Information Technology; Retail \& Cons/Bus Prod/Serv; and Other):

$$
R E V_{i t}=\alpha_{k}+\beta_{k} \text { firmage }_{i t}+\sum_{s=1}^{4} v_{s k} \text { DSTATE }_{i s}+\varepsilon_{i t}
$$

This baseline model is simple in that it conjectures that firm $i$ 's historical revenue in calendar year $t$ depends only on firm age in year $t$, and the state that the firm is headquartered in. Firm

\footnotetext{
${ }^{12}$ In the setting of pay discrimination, a model of what pay should be for all employees in the absence of discrimination is first estimated on non-minorities using explanatory variables such as education, job performance and job tenure. The parameters from this model are then used to predict pay for minorities based on their education, job performance and job tenure. If predicted pay for minorities is substantially more than their actual pay, then this method argues that there is cause to suspect that minorities are being discriminated against with regard to pay.
} 
age is a proxy for firm maturity, with more mature firms being more likely to have converted tangible and intangible assets into ongoing revenue. State dummies (CA, MA, NY and TX) are proxies for high density geographic externalities, e.g., being located in Silicon Valley. We expect $\beta_{k}$ to be positive, but make no magnitude or sign predictions for any $v_{s k}$.

We then project the parameters obtained by estimating equation (1) using OLS onto the full set of 2,386 firm-year forecasted revenues. This yields 2,386 historically-grounded conditional revenue projections - that is, estimates of what revenues would be expected to be given the revenues private venture-backed firms' experience, and the age and state of the firm.

However, for some firms we know more information than just their age and state. In particular, and as shown visually in figure 1, we often know a firm’s lagged revenues (either actual or forecasted) in a given year. ${ }^{13}$ When $R E V_{i, t-1}$ is available, we therefore exploit this additional information, thereby obtaining a more precise historical projection of revenues, by replacing the historical projection of revenues obtained through equation (1) with that obtained through equation (2) below, also estimated separately by industry sector:

$$
R E V_{i t}=\alpha_{k}^{\prime}+\gamma_{k}^{\prime} R E V_{i, t-1}+\beta_{k}^{\prime} \text { firmage }_{i t}+\sum_{s=1}^{4} v_{k s}^{\prime} D_{S T A T E}+\varepsilon_{i t}^{\prime}
$$

We expect firm growth to manifest itself in $\gamma_{k}^{\prime}$ being greater than one for all industry sectors, and $\beta_{k}^{\prime}$ to be positive for all industry sectors. However, as in equation (1) we do not make magnitude or sign predictions for any $v_{k s}^{\prime}$.

The mechanical application of equation (2) is appropriate for generating historical projections of one-year-ahead revenue, since one-year-lagged revenue is an actual number. However, when generating historical projections of revenue at horizons beyond one year, oneyear-lagged revenue mechanically taken from the VentureOne database is a management forecast number. Thus, to obtain (say) two-year-ahead historical projections of revenue, we project the parameter estimates from equation (2) onto the characteristics of firms with two-yearahead revenue forecasts and non-missing values of the independent variables listed in (2), where $R E V_{i, t-1}$ is not the one-year-ahead revenue forecast made by the firm but rather is the historical

\footnotetext{
${ }^{13}$ Some firms have more than one year of lagged revenues. However, lagged revenues beyond one year add little explanatory power over and above revenue lagged one year.
} 
projections of one-year-ahead revenue already calculated in the previous step. We do likewise for three-, four- and five-year-ahead revenue forecasts and thereby obtain on a firm-yearobservation by firm-year-observation basis historically-grounded conditional projections of revenues that use the greatest amount of firm-specific information. We denote such revenue predictions as HPREDREV $V_{\text {it }}$.

Finally, denoting MANFCASTREV $V_{i t}$ as the forecast of revenue made by manager of firm $i$ for calendar year $t$, we define the revenue forecast error for firm $i$ for calendar year $t$ as:

$$
\text { FEREV } V_{i t}=\frac{M A N F C A S T R E V_{i t}-H P R E D R E V_{i t}}{H P R E D R E V_{i t}}
$$

The forecast errors defined in equation (3) are then averaged, either unconditionally or by the length of the forecasting horizon. ${ }^{14}$ For expenses, we apply the same methods as just described for revenues. For revenues and expenses, we compute mean forecast errors as weighted averages, where the weights are the inverse of the standard errors of the predicted revenues. This explicitly takes into account that the predicted values of revenues obtained by applying equation (2) will be much more precise than will those obtained from equation (1), and likewise for expenses. ${ }^{15}$ Accompanying t-statistics are also computed using these same weights. Since net income can be (and indeed, typically is) negative, forecast errors for net income are defined in terms of profitability, namely forecasted net income less predicted net income, scaled by predicted revenues, where predicted net income equals predicted revenues less predicted expenses:

$$
\text { FENI }_{i t}=\frac{\text { MANFCASTNI }_{i t}-\left(\text { HPREDREV }_{i t}-\text { HPREDEXP }_{i t}\right)}{H P R E D R E V_{i t}}
$$

\footnotetext{
${ }^{14}$ We base our inferences on mean forecast errors, rather than median forecast errors, because we estimate equations (1) and (2) using OLS. The reason for using OLS is that we assume that when making their forecasts, managers face a symmetric squared error loss function, rather than a symmetric linear loss function. As a result, the historicallygrounded conditional projections obtained by applying the parameter estimates from equations (1) and (2) onto firmspecific data are such that if equations (1) and (2) are well specified, the expected value of the mean forecast error as defined in equation (3) will be zero.

${ }^{15}$ Very similar inferences obtain if equal weights—i.e., simple averages—are calculated instead.
} 


\section{4. $\quad$ Results}

4.1 Comparison of the drivers of historical vs. management forecasted revenues, expenses and net income

Table 4 reports the results of estimating equations (1) and (2) for firms' historical and forecasted revenues, expenses, and net incomes (panels A and B, respectively). For each financial variable, equation (1) is the left hand side regression in the table, while equation (2) is the right hand side regression. The results reported are the mean values obtained from estimating the regressions separately for each of VentureOne's four industry sectors (Healthcare/Biotech; Information Technology; Retail \& Consumer/Business Products/Services; and Other). Intercepts and four state dummies (CA, MA, NY, TX) are estimated but for reasons of parsimony their parameter estimates are not reported.

We highlight the following results from table 4. First, in terms of equation (1), we find that as expected, the historical revenues, expenses and net incomes of private venture-backed companies reliably increase with age. Next, in terms of equation (1), managers' forecasts of revenues, expenses and net incomes also reliably increase with firm age, although they do so at a rate relative to historical revenues, expenses and net incomes that is only significantly larger for net income (comparison of coefficient estimates on firm age across panel B versus panel A).

Table 4 also demonstrates that where possible, including the one-year lagged value of the dependent variable is very important, in that the t-statistics on the parameter estimates on the one-year lagged values of dependent variables are highly significant, and in four of the six regressions, result in insignificant coefficients on firm age. Moreover, unlike the insignificant differences on between firm age coefficients in equation (1) for revenues and expenses, the coefficients on one-year lagged revenues and expenses are very significantly larger for forecasts than for actuals.

Finally, we refine equation (2) when net income is the dependent variable to allow for different coefficients on positive and negative one-year lagged net income. This is to determine if managers are optimistic both when their most recent actual net income is positive and when it is negative. Although consistent with this view, the point estimates on positive (negative) oneyear lagged net income are larger (smaller) for forecasts than for actuals, unreported tests indicate that the differences are not statistically significant. 


\subsection{Mean management forecast errors for revenues, expenses and profitability}

Table 5 and figure 3 report the most important results of our study, namely the mean percentage errors for managers' forecasts of revenues, expenses and profitability. The forecast errors analyzed in table 5 are those obtained by applying the historically-grounded conditional projection method detailed in section 3.1, with two refinements. First, the inability of equations (1) and (2) to fit perfectly historical data on occasion yields a small number of negative predicted revenues or predicted expenses. ${ }^{16}$ Since negative revenues or expenses are not possible, we exclude such observations. Also, predicted revenues or expenses are sometimes positive but very small. When divided into forecast numbers, this can result in extreme outlier forecast errors as defined via equation (3). We therefore exclude observations where revenue or expense forecast errors exceed 2,500\%. ${ }^{17}$ The small and largely insignificant mean in-sample forecast errors reported in panel A of table 5 for historical revenues, expenses and profitability indicate that the refinements outlined above do not materially distort the mean of the forecast error distribution relative to its theoretical value.

As emphasized in the introduction of our paper, our goals in estimating mean management forecast errors are twofold: [1] To document for our sample of private venturebacked young companies whether and how the signs and magnitudes of any management forecast biases vary as a function of the length of the forecasting horizon, and [2] to investigate whether and why biases in managers' multi-year revenue, expense or profitability forecasts reflect strategic behavior on the part of managers.

The motivation behind our first goal is centered in prior work in entrepreneurship that has argued theoretically, and concluded empirically, that entrepreneurs are hard-wired to be highly optimistic and risk seeking (e.g., Simon, Houghton and Aquino, 1999; Rigotti, Ryan and Vaithianathan, 2003; Landier and Thesmar, 2004; Puri and Robinson, 2005; Lowe and Ziedonis, 2006). If this is the case, then we would expect the managers making the forecasts provided by firms to VentureOne to be similarly hard-wired in terms of behaviorally-based optimism, leading us to predict that those managers' forecasts of revenues, expenses and profitability will be

\footnotetext{
${ }^{16}$ For example, less than $0.5 \%$ of the in-sample fitted values in estimating equation (1) for revenues are negative.

${ }^{17}$ The fraction of observations excluded due to these criteria is very small. For example, less than $0.8 \%$ of revenue forecast errors need to be deleted.
} 
optimistic at all forecasting horizons, be present for all firms, and increase as the length of the forecasting horizon increases.

The first result that we highlight in panel A of table 5 and panel A of figure 3 is consistent with this prediction. This is that managers' forecasts of profitability are optimistic at all horizons, and become substantially more optimistic as the forecasting horizon increases from one- to five-years-ahead. For all firm-year data pooled together, managers of private venturebacked U.S. firms make one-year-ahead forecasts of net income scaled by predicted revenues that are on average 35\% too high, and this bias rises monotonically such that five-year-ahead forecasts of profitability are $122 \%$ too high.

However, separately analyzing managers' revenue and expense forecasts indicates that managerial optimism is not invariably present. We report in panel A of table 5 that one-yearahead revenue forecasts are reliably understated (i.e., pessimistic) by an average of $11 \%$, whereas two- through five-year-ahead revenue forecasts are reliably and increasingly overstated (i.e., optimistic). The optimism bias in revenue forecasts monotonically increases as the forecast horizon increases (42\% two-years-ahead rising to 212\% five-years-ahead). Also, whereas oneyear-ahead expense forecasts are reliably understated (i.e., optimistic) by an average of 28\%, two- through five-year-ahead expense forecasts are either unbiased or reliably overstated (i.e., pessimistic). And as is the case with revenues, the pessimism bias in expense forecasts monotonically increases as the forecast horizon increases (being 25\% three-years-ahead, 41\% four-years-ahead, and $80 \%$ five-years-ahead). ${ }^{18}$

\subsection{Strategic distortion of forecasts by managers}

The above documented mixture of optimism and pessimism in part motivates our investigation into whether and why biases in managers' multi-year revenue, expense or profitability forecasts reflect strategic behavior on the part of managers. More importantly, though, is the fact that private venture-backed firms face very strong incentives to intentionally and strategically overstate their forecasts of long-term future net income to external parties. This

\footnotetext{
${ }^{18}$ Unreported tests indicate that qualitatively similar results to those in panel A of table 5 obtain if year dummies are added to equations (1) and (2); if the miscellaneous industry sector defined by VentureOne as Other is excluded from the analysis; if profitability is directly modeled, rather than being determined by separate modeling of revenues and expenses; if the computation of forecast errors is limited to firm-years where equation (1) only is well defined; and if the computation of forecast errors is limited to firm-years where equation (2) only is well defined, that is, firm-years where the lagged value of the financial variable is available.
} 
is because the higher is the firm's perceived long-term net income, the more likely is the forecasting firm to secure its next round of venture financing - without which the firm may well go out of business, given the deliberately staged nature of venture capital. Moreover, the terms of new funding are important to existing managers. The higher is the pre-money firm value in subsequent funding rounds, the lower is the dilution to current equity holders. The greatly heightened need that young high-technology companies have for capital, relative to more mature public companies, therefore makes them a powerful setting for studying strategic forecasting.

We view the already presented evidence on long-term forecast biases (Table 5, panel A) as consistent with this view, because although three- through five-year-ahead expense forecasts are on average reliably pessimistic, three- through five-year-ahead revenue forecasts are reliably even more optimistic, leading to one-year-ahead profitability forecasts that are optimistically biased by between $67 \%$ and $122 \%$. Although potentially post hoc as an explanation, we conjecture that managers realize that although their predictions of the size of future revenues will be difficult for venture investors to disprove, the relations between future revenues and expenses are largely constrained. That is, we suggest that managers realize that venture investors will (and do) pore over their pro-forma spreadsheets with a view to making sure that conditional on managers' long-term revenue projections, long-term expense projections “exhibit reasonable internal consistency." We propose that this revenue-conditional constraint is what leads managers to make what appear to be pessimistic forecasts about their long-term future expenses.

Separate from results already discussed, we develop the idea that managers make strategic forecasts by hypothesizing that managers of private venture-backed firms are more likely to impart strategic bias to their financial forecasts the harder (costlier) it is for venture funds to verify the existence and magnitude of the firms' economic assets. Our reasoning here draws on the insights of Rogers and Stocken (2005), who establish that managers of public firms are more likely to bias their forecasts when it is more difficult for investors to detect that they have misrepresented their information. In our setting, we propose that the cost of verification is larger the more intangible-intensive is a firm, since intangible assets consist of $R \& D$, patents, trademarks, copyrights, brand names, intellectual capital, innovative ideas and processes, all of which typically lack physical substance or liquid secondary markets, thereby making them hard to both audit and value (Lev, 2001). Lacking direct measures on R\&D, patents, etc., we empirically test this view by using the industry sector that VentureOne classifies firms into as a 
proxy for intangible intensity. We argue that firms in the Healthcare/Biotech industry sectorwhich are predominantly biotechnology companies—are more intangible intensive than are firms in the Information Technology sector, which in turn are more intangible intensive than are firms in the Retail \& Consumer/Business Products/Service sector. ${ }^{19}$

Panels B - D of table 5, which compute and present mean management forecast errors for revenues, expenses and profitability by industry sector, report evidence that we interpret as being consistent with the verification hypothesis. Comparing panels B, C and D indicates that the profitability forecast bias for biotechnology firms (with very intangible and therefore hard-toverify assets) exceeds the profitability forecast bias for IT firms (moderately difficult-to-verify assets) which in turn exceeds the profitability forecast bias for retail firms (easy-to-verify assets). Drilling into the components of profitability, consistent with the proposition that revenue forecasts are harder for venture investors to verify than expense forecasts, particularly when the underlying economic assets are hard-to-verify, we find that biotechnology firms' one- and fiveyear-ahead revenue forecasts are respectively $49 \%$ and 305\% optimistic, IT firms' one- and fiveyear-ahead revenue forecasts are $27 \%$ pessimistic and $204 \%$ optimistic, respectively, and retail firms' one- and five-year-ahead revenue forecasts are $41 \%$ pessimistic and only $3 \%$ optimistic, respectively. Revenues exhibit a similar ordering of biases across the three industry sectors.

In table 6 we formally test whether the average differences suggested in panels B - D of table 5 are statistically significant. Table 6 reports the results of regressing table 5 's management forecast error on the three key industry sector dummies, controlling for forecast horizon, firm age, and headquarter location. The F-test p-values reported at the bottom of table 6 indicate that in every case the average differences between forecast errors across industry sectors (whether revenue, expense or profitability) are significantly in the predicted directions. Based on the results in Tables 5 and 6 we conclude that there is reliable evidence in our sample of firms that managers strategically bias their forecasts in a way that takes advantage of the varying industry-specific difficulties facing venture funds in verifying the legitimacy of the economic assets underlying firms' multi-year forecasts.

\footnotetext{
${ }^{19}$ We do not report results for the industry sector defined by VentureOne as "Other" due to this sector having relatively few available forecast errors, particularly at longer forecasting horizons.
} 


\subsection{Strengths and weaknesses of the historically-grounded conditional prediction method}

The major conceptual advantage to the historical prediction method of estimating the degree of bias in managers' financial forecasts is that the method can be applied to every forecast for which the independent variables in equations (1) and/or (2) are available. The method does not require that there be an ex-post realization of the financial variable being forecasted. Requiring that there be long-term ex post actual results to compare against long-term forecasts by young firms would substantially reduce the number of data points, and likely impart selection problems to such observations. This is because young companies, particularly those financed by venture capital, face either significant going-concern risks or the possibility of exit as a trade sale. They are therefore quite likely not to survive as an independent company five years into the future, biasing the realizations of revenues, expenses and net income to compare against managers' forecasts to the most successful companies-typically, but not exclusively those that go IPO. In addition, venture-backed early stage companies often go through multiple changes in their business model. Relative to established companies, forecasts made for early stage firms are more likely to manifest an "apples-to-oranges" mismatch between the business model in place at the time of the forecast, and the business model in place at the time of the ex-post realization.

There are, however, some potential drawbacks and inferential risks involved in applying the historical prediction method to our setting. We now elaborate on these and describe our approaches to assessing their significance in our particular setting.

The first potential problem with the historical prediction method is that unbiased historical predictions from equations (1) and (2) require that the VentureOne data used in estimating the equations be a random sample of all historical financial results experienced by live private venture-backed firms. ${ }^{20}$ This is likely not the case in that VentureOne obtains approximately three-quarters of its actual, historical data from firms’ IPO filing documents. ${ }^{21}$ In contrast, the fraction of all venture-backed firms that go public is only 10\% - 15\% (Armstrong, Dávila and Foster, 2006). Since firms that go IPO are on average more successful than those that do not, this selection problem in our setting will likely lead to upward-biased historicallygrounded conditional predictions of revenues, expenses and net income. Per equations (3) and

\footnotetext{
${ }^{20}$ Firms must be alive to generate actual financial data. However, firms making financial forecasts also make their forecasts assuming they will be alive over the forecasting horizon. Thus, the requirement that a firm be alive rather than dead does not impose a differential bias across historical versus forecasted revenues, expenses and net income.

${ }^{21}$ The remaining one quarter of VentureOne actuals come from press releases and other secondary sources.
} 
(4) in section 3.1, this will then lead to downward-biased mean forecast errors - suggesting that if anything, the mean forecast errors we report in table 5 are too small, not too large.

A second potential drawback to the historical prediction method is that a firm's decision as to whether to provide VentureOne with financial forecasts may be correlated with economic factors not modeled in equations (1) and (2). Stated differently, the forecasts voluntarily provided by managers to VentureOne may not be a random sample of those available in the business plan spreadsheets of the population of private venture-backed U.S. firms’ CFOs. Although all voluntary disclosures by managers create selection concerns for researchers, it may be that the issue is more severe in our data because firms typically only submit forecasts to VentureOne when they are seeking venture funding. It might therefore be that firms only submit revenue forecasts to VentureOne when their true forecasts are strong/high, and not when they are weak/low, because obtaining venture funding is more likely in the former case than in the latter. Unfortunately, without access to a random sample of the internal forecasts of firms, particularly those that do not submit forecasts to VentureOne, we cannot empirically measure the severity of the inferential threat posed by this concern. However, we note that needing further venture funding is not at all an unusual state-of-the-world for venture-backed firms to be in -in fact, it is the most common because venture funds deliberately stage (i.e., spread out over time) the total amount of funding that might be needed for the firm to turn cash flow positive into several (even many) rounds of financing spread over three to eight years. Moreover, although firms appear to stop submitting forecasts to VentureOne when they believe that their next round of financing will be an IPO, potentially leading to genuinely very strong forecasts being omitted from VentureOne's database, this may be counteracted by overrepresentation of forecasts by firms that are highly anxious to obtain financing because they are financially very weak, and because of that desperation they provide VentureOne with deliberately very optimistic forecasts.

In appendix A we detail the results of tests we undertook to try to quantify the potential biases described above. In our first test, we assess the correspondence between our historicallygrounded conditional projections and ex-post historical actual observations by employing an outof-sample test. We use a database created and used by Armstrong, Dávila and Foster (ADF, 2006), who examine the valuation of venture-backed U.S. companies using 502 venture-backed companies that went public during 1996-2000. When we re-estimate our revenue and expense models_-equations (1) and (2) — using only the subset of firms in the VentureOne database that 
went public, and then project the parameter estimates onto the characteristics of the subset of firms in the ADF database that are not in the VentureOne database, we find that for revenues, expenses and profitability, the mean differences between the actual values of the financial variable less the historically-grounded conditional projection are insignificantly different from zero. Such results lead us to conclude that at least for the subset of VentureOne firms that go public, our use of historically-grounded conditional projections does not seem to impart systematic bias to the benchmarks against which manager's forecasts are being compared.

In our second test, we directly compensate for the differences in the ex-post success or failure between the firms whose historical data we use in developing the historical prediction model, and the firms whose management forecasts we compare to the historical predictions. Specifically, we augment equations (1) and (2) by including dummy variables that span the full set of the categories of ultimate firm status coded by VentureOne in their financial database in March 2005 (namely Out of Business; In Bankruptcy; Private and Independent; In IPO Registration; Acquired/Merged; and Publicly-Held). We then follow the same approach as described in section 3.1 to arrive at what we term "ex-post business success adjusted historicallygrounded conditional projections” or 'success-adjusted historical projections' for short. Empirically, we find that the general pattern in the resulting mean forecast errors is similar to those reported in table 5-for example, that management forecasts of revenues, expenses and profitability are highly biased at long horizons. The main difference is that we do no longer observe pessimism in one-year-ahead revenue forecasts. We speculate that although this may indeed be true, it may also be that our success-adjusted historical projections reflect overcompensation on our part for sample selection bias. This is because at the time that managers make their forecasts, neither they nor an outside observer knows for sure which category of ultimate firm status the firm will occupy, but our projection of the parameter estimates obtained from including ultimate firm status dummy variables in developing the success-adjusted historical projections assume that they do.

Overall, while the historical projection method carries notable inferential risks, particularly in data such as VentureOne's set of actual and forecasts, it appears to be sufficiently robust for us to conclude that there is reasonable evidence that the financial forecasts made by managers of private venture-backed companies are biased, and strategically so. 


\subsection{Future work}

We view our paper as only a first step in seeking to understand the pervasive and crucial managerial responsibility of developing multi-year financial statement forecasts. Many novel and worthwhile questions remain to be addressed. For example, do strategic forecasts truly increase the probability of venture-backed firms obtaining funding, or the amount of funding, or the terms of the funding (such as the firm's pre-money valuation)? Does managerially imparted bias help or hinder the ability of the firm to hire employees, sign up new customers for its products, or attract analyst following? We also think it would be worthwhile for future research to study to what extent, and why or why not, our results generalize to public firms, and to nonventure-backed private companies. This would likely involve the use of surveys.

We also believe that non-U.S. data warrants scrutiny as it becomes more available. The VentureOne forecast database contains some data on the variables we analyze in this study for European venture-backed firms. In appendix B, we report preliminary evidence on actual versus forecasted revenues, expenses and net income (and associated estimates of managerial forecast biases) for a relatively small set of European firms. Given the different cultural, economic and capital markets that operate in Europe (e.g., more reliance on debt financing), we suggest that it would be worth, among other research thrusts, to document the factors (if any) attenuate or exacerbate the horizon biases that we document, both within and across countries. ${ }^{22}$

\section{Conclusion}

In this paper we have provided a preliminary analysis of the properties and determinants of managers' multi-year financial forecasts. We then deepened our inquiry by probing whether, by how much, and why biases in managers' forecasts revenues, expenses and profitability depend on forecasting horizon and the verifiability of firms' assets. We used the one- to fiveyear-ahead forecasts voluntarily reported by private venture-backed U.S. firms because public companies hardly ever make known managers’ internal multi-year financial projections to outsiders. We also introduced a different method of measuring financial forecast bias that

\footnotetext{
${ }^{22}$ For example, Hirst, Koonce and Venkataraman (2006) report experimental evidence consistent with the idea that management forecasts that are disaggregated in nature are viewed by investors as more precise, less biased and more credible. We do not find this in our data-specifically, we find the same magnitude of horizon biases in U.S. managers' forecasts of revenues whether the revenue forecast is or is not accompanied by a forecast of net income.
} 
compares forecasts to historically-grounded conditional projections, rather than to ex-post actual results.

Subject to the limitations and unresolved uncertainties in the application of the historical projection method in our setting, and the marked limitations in generalizing to either publicly traded companies or non-venture-backed private firms, our results suggest that on average, managers' forecasts of firm revenues and profitability are optimistic, but that this optimism increasing greatly as the forecast horizon rises to from one- to five-years-ahead. At the same time, however, we also conclude that profitability forecasts appear to have a strategic component to them because revenue, expense and profitability forecasts are not uniformly optimistic. Instead, revenue (expense) forecasts appear to be asymmetrically but moderately pessimistic (optimistic) at short horizons, and asymmetrically but hugely optimistic (pessimistic) at long horizons. Furthermore, we also find that biases in revenue and expense forecasts are more severe when the intangible-intensity_our proxy for the inverse of verifiability—of firms' assets is high. Since venture-backed firms are predominantly those with intangible assets, we believe that further research into how, when, and why entrepreneurial managers act strategically, and whether, how, when and why venture capital investors detect and adjust for such strategic behavior, is a worthwhile path to pursue. 


\section{REFERENCES}

Armstrong, C., Dávila, A., and G. Foster, 2006. Venture-backed private equity valuation and financial statement information. Review of Accounting Studies 17: 119-154.

Beuselinck, C., Deloof, M., and S. Manigart, 2005. Private equity and earnings quality. Working paper, Vlerick Leuven Gent.

Blinder, A.S. 1973. Wage discrimination: Reduced form and structural variables. Journal of Human Resources 8: 436-455.

Brown, L.D., and H.N. Higgins, 2005. Managers’ forecast guidance of analysts: International evidence. Journal of Accounting and Public Policy, 24, 4:280-299.

Chan, L.K.C., Karceski, J., and J. Lakonishok, 2003. The level and persistence of growth rates, Journal of Finance 58, 643-684.

Clatworthy, M.A., Peel, D.A., and P.F. Pope, 2005. Are analysts’ loss functions asymmetric? Working paper, Lancaster University.

Cochrane, J.H., 2005. The risk and return of venture capital. Journal of Financial Economics 75, 3-52.

Dávila, A., 2005. An exploratory study on the emergence of management control systems: Formalizing human resources in small growing firms. Accounting, Organizations and Society 30 (3): 223-248.

Dávila, A., and G. Foster, 2005. Management accounting systems adoption decisions: Evidence and performance implications from startup companies. The Accounting Review 80 (4): 10391068.

Dávila, A., Foster, G., and M. Gupta, 2003. Venture capital financing and the growth of startup companies. Journal of Business Venturing 18, 689-708.

Dechow, P.M., and R.G. Sloan, 1997. Returns to contrarian investment strategies: Tests of naïve expectations hypothesis. Journal of Financial Economics 43, 3-27

Frankel, R., McNichols, M., and G.P. Wilson, 1995. Discretionary disclosure and external financing. The Accounting Review 70: 135-150.

Gompers, P.A., and J. Lerner, 2000. The Venture Capital Cycle. Cambridge, MA: MIT Press.

Gompers, P.A., Lerner, J., and D. Scharfstein, 2005. Entrepreneurial spawning: Public corporations and the genesis of new ventures, 1986 to 1999. Journal of Finance 60 (2): 577614.

Haemmig, M., 2006. Global Venture Capital Investment Update 2006. In The Globalization of Venture Capital. Berne/Switzerland, Haupt Publisher.

Hand, J.R.M., 2005. What drives the top line? Nonfinancial determinants of sales revenue in private venture-backed firms. Working paper, UNC Chapel Hill. 
Hand, J.R.M., 2006. Give everyone a prize? Employee stock options in venture-backed firms. Working paper, UNC Chapel Hill.

Healy, P.M., Hutton, A.P., and K.G. Palepu, 1999. Stock performance and intermediation changes surrounding sustained increases in disclosure. Contemporary Accounting Research 16: 485-520.

Hirst, D.E., Koonce, L., and S. Venkataraman, 2006. How disaggregation enhances the credibility of management earnings forecasts. Working paper, University of Texas (Austin).

Hutton, A.P., 2005. Determinants of managerial earnings guidance prior to Regulation Fair Disclosure and bias in analysts' earnings forecasts. Forthcoming, Contemporary Accounting Research.

Hutton, A.P., and P.C. Stocken, 2005. Effect of reputation on the credibility of management forecasts. Working paper, Dartmouth College.

Hutton, A.P., Miller, G.S., and D.J. Skinner, 2003. The role of supplementary statements with management earnings forecasts. Journal of Accounting Research 41: 867-890.

Kasznik, R., and B. Lev, 1995. To warn or not to warn: Management disclosures in the face of an earnings surprise. The Accounting Review 70: 113-134.

Landier, A., and D. Thesmar, 2005. Financial contracting with optimistic entrepreneurs. Working paper, New York University.

Lang, M., and R. Lundholm, 2000. Voluntary disclosure during equity offerings: Reducing information asymmetry or hyping the stock? Contemporary Accounting Research 17: 623663.

Lev, B., 2001. Intangibles: Management, measurement, and reporting. The Brookings Institution, Washington, D.C.

Lowe, R.A., and Ziedonis, A.A., 2006. Overoptimism and the performance of entrepreneurial firms. Management Science 52 (2): 173-186.

Miller, G.S., 2002. Earnings performance and discretionary disclosure. Journal of Accounting Research 40: 173-204.

National Venture Capital Association, 2004. Venture Impact 2004: Venture capital benefits to the U.S. economy.

Oaxaca, R. 1973. Male-female wage differentials in urban labor markets. International Economic Review, 14: 693-709.

Oaxaca, R., and M. Ransom, 1994. On discrimination and the decomposition of wage differentials. Journal of Econometrics 61: 5-21.

Patell, J.M., 1976. Corporate forecasts of earnings per share and stock price behavior: Empirical tests. Journal of Accounting Research 14: 246-276. 
Penman, S.H., 1980. An empirical investigation of the voluntary disclosure of corporate earnings forecasts. Journal of Accounting Research 18: 132-160.

Puri, M., and D.T. Robinson, 2005. Optimism and economic choice. Working paper, Duke University.

Rigotti, L., Ryan, M., and R. Vaithianathan, 2003. Tolerance of ambiguity and entrepreneurial innovation. Working paper, Duke University.

Rogers, J.L., and P.C. Stocken, 2005. Credibility of management forecasts. The Accounting Review 80, 4: 1233-1260.

Rosa, C.D.M., and K. Raade, 2006. Profitability of venture capital investment in Europe and the United States. Working paper, European Economy European Commission, DirectorateGeneral for Economic and Financial Affairs. Brussels.

Seppä, T.J., 2003. Essays on the valuation and syndication of venture capital investments. Ph.D. dissertation, Helsinki University of Technology.

Simon, M., Houghton, S.M., and K. Aquino, 1999. Cognitive biases, risk perception, and venture formation: How individuals decide to start companies. Journal of Business Venturing, 15: 113-134.

Wasley, C.E., and J.S. Wu, 2006. Why do managers voluntarily issue cash flow forecasts? Journal of Accounting Research 44: 389-429.

Waymire, G., 1984. Additional evidence on the information content of management earnings forecasts. Journal of Accounting Research 22: 703-718. 


\section{APPENDIX A \\ Analysis of the severity of sample selection biases in VentureOne's set of ex-post historical actuals and ex-ante management forecasts}

\section{A.1 Correspondence between historically-grounded projections and historical actuals}

To assess the correspondence between our historically-grounded conditional projections and ex-post historical actual observations, we employ an out-of-sample test using a different database than VentureOne's. This different database is the one created and used by Armstrong, Dávila and Foster (ADF, 2006), who examine the valuation of venture-backed U.S. companies using 502 venture-backed companies spread across six industries. Every firm in ADF's dataset undertook an IPO during 1996-2000, and the financial statement data collected from IPO and other filing documents for ADF’s firms covers 1993-2005.

We first re-estimate our revenue and expense models — equations (1) and (2) —using only the subset of firms in the VentureOne database that went public. Because ADF's data is more clustered in calendar time than is VentureOne's we also include slope dummies on the lagged value of revenues or expenses in equation (2) when it applies, where the indicator variable equals one if the firm-year is between 1997 and $2000 .^{23}$

The parameter estimates from our estimation of equations (1) and (2) on the subset of VentureOne firms that went public are then projected onto the characteristics of the subset of firms in the ADF database that are not in the VentureOne database. ${ }^{24}$ This yields projections for the ADF subset of what actual revenues, expenses and profitability would be if the models we estimated on the subset of VentureOne firms that went public are appropriately applied to a random sample of all venture-backed firms that go public.

We define forecast errors in the ADF data subset as the actual value of the financial variable less the historical projection, scaled by the actual value. Table A.1 below presents the mean forecast error for revenues, expenses and profitability. The mean forecast errors for all three financial series are not significantly different from zero. These results lead us to conclude

\footnotetext{
23 The results presented below are qualitatively similar when the indicator variables interacted with the lagged value of the financial variable for observations in 1997-2000 are replaced with indicator variables for those years.

${ }^{24}$ Fifteen firm-year observations in the ADF dataset for each of the revenue, expense and net income series were removed due to overlap with the VentureOne forecast database.
} 
that at least for the subset of VentureOne firms that go public, our use of historically-grounded conditional projections would not seem to impart systematic biases into our inferences.

\section{Table A.1}

Mean percentage management forecast errors for revenues, expenses and profitability by forecasting horizons (Dataset $=$ firms in the dataset used by Armstrong, Dávila and Foster, 2006, that are not in the VentureOne dataset described in table 1)

\begin{tabular}{l|ll|ll|ll}
\hline Statistics & \multicolumn{2}{c}{ Revenues } & \multicolumn{2}{c}{ Expenses } & \multicolumn{2}{c}{ Profitability } \\
\hline Mean (t-statistic) & $2 \%$ & $(0.8)$ & $3 \%$ & $(1.6)$ & $-1 \%$ & $(-0.2)$ \\
\hline
\end{tabular}

\section{A.2 Controlling for the ex-post status of the firm}

In our second test, we directly compensate for the differences in the ex-post success or failure between the firms whose historical data we use in developing the historical prediction model, and the firms whose management forecasts we compare to the historical predictions. Table A.2 below reports the relative frequencies of the categories of ultimate firm status coded by VentureOne in their financial database in March 2005 (Out of Business; In Bankruptcy; Private and Independent; In IPO Registration; Acquired/Merged; and Publicly-Held).

Table A.2

\section{Relative frequency of sample firms’ business status in March 2005}

\begin{tabular}{lcc}
\hline $\begin{array}{l}\text { Business status code } \\
\text { specified by VentureOne }\end{array}$ & Actuals & $\begin{array}{c}\text { Managers' } \\
\text { forecasts }\end{array}$ \\
Acquired or merged & $8.7 \%$ & $34.6 \%$ \\
In bankruptcy & $<0.1$ & $<0.1$ \\
In IPO registration & 1.1 & $<0.1$ \\
Out of business & 3.4 & 24.4 \\
Private \& independent & 13.7 & 35.8 \\
Publicly-held & 73.0 & 5.1 \\
\hline
\end{tabular}

There are clearly substantial differences between actual and forecasted observations in our dataset. Firm-year observations belonging to firms that went public appear to be oversampled in the actuals data (suggesting that historically-grounded conditional projections will if anything be too big, not too small). In contrast, firm-year observations belonging to firms that went out of business appear to be oversampled in the forecast data (suggesting that mean forecast 
errors may also be downward-biased because VentureOne's set of managers' forecasts may if anything be too low relative to the population of forecasts in firms' spreadsheets).

We attempt to take the differences in table A.2 into account by augmenting equations (1) and (2) through the inclusion of dummy variables that span the full set of ultimate firm status. We then follow the same approach as in section 3.1 of projecting the parameters estimated on only actuals data onto forecasted firms' characteristics to arrive at what we term "ex-post business success adjusted historically-grounded conditional projections" or 'success-adjusted historical projections’ for short. The aggregate sample results are shown in table A.3.

Table A.3

Mean percentage management forecast errors for revenues, expenses and profitability by forecasting horizon, after conditioning on firms' ultimate business status (at March 2005)

\begin{tabular}{l|rrr|rrr|rrr}
\hline & \multicolumn{4}{c}{ Revenues } & \multicolumn{3}{c}{ Expenses } & \multicolumn{3}{c}{ Profitability } \\
\hline & \# obs. & Mean & t-stat. & \# obs. & Mean & t-stat. & \# obs. & Mean & t-stat. \\
\hline Historical data & 6,670 & $0 \%$ & $(0.1)$ & 6,120 & $3 \%$ & $(1.4)$ & 5,974 & $-12 \%$ & $(-0.8)$ \\
\hline 1 year ahead & 1,130 & $28 \%$ & $(4.4)$ & 598 & $4 \%$ & $(0.0)$ & 562 & $22 \%$ & $(1.5)$ \\
2 years ahead & 413 & $115 \%$ & $(8.1)$ & 297 & $58 \%$ & $(5.4)$ & 274 & $72 \%$ & $(5.8)$ \\
3 years ahead & 271 & $252 \%$ & $(10.1)$ & 233 & $138 \%$ & $(6.6)$ & 213 & $100 \%$ & $(7.7)$ \\
4 years ahead & 194 & $295 \%$ & $(9.9)$ & 179 & $191 \%$ & $(7.1)$ & 164 & $113 \%$ & $(9.2)$ \\
5 years ahead & 120 & $355 \%$ & $(8.9)$ & 115 & $254 \%$ & $(6.6)$ & 109 & $130 \%$ & $(10.4)$ \\
\hline
\end{tabular}

When compared to panel A of table 5 (which does not seek to control for differences in ultimate firm status), table A.3 suggest that the general pattern in the resulting mean forecast errors is similar to those reported in table 5. For example, management forecasts of revenues, expenses and profitability remain highly biased at long horizons, and forecast bias increases as the length of the forecasting horizon increases. The main difference is that we do no longer observe pessimism in one-year-ahead revenue or expense forecasts. We speculate that although this may indeed be the case, it could also be that our success-adjusted historical projections in fact overcompensate for sample selection bias. This is because at the time managers make their forecasts, neither they nor an outside observer knows for sure which category of ultimate firm status the firm will occupy. However, our projection of the parameter estimates obtained from including ultimate firm status dummy variables in developing the success-adjusted historical projections assume that ultimate firm status is known at the time of the forecast. 


\section{APPENDIX B}

\section{Preliminary Evidence on Private Venture-Backed European Companies}

Since its first major growth spurt in the late 1970s, the U.S. venture capital industry has dominated the global venture market. For example, Haemmig (2006) reports that global venture capital investments in 2005 were $\$ 31.9$ billion, of which $\$ 21.1$ billion or $69 \%$ were U.S. in origin, with only $\$ 4.5$ billion or $15 \%$ being European.

VentureOne has been extensively analyzing venture-backed U.S. companies since the early 1990s. In recent years it has also expanded its attention to include venture-backed firms outside of the U.S. Of the total firm-year observations in the VentureOne database provided to us, approximately $15 \%$ were for European companies.

Our preliminary analysis of European data suggests that it differs from U.S. data in several respects. One major difference is the scarcity of European management forecasts beyond two-years-ahead in the up to five-year-ahead forecasting horizon. Of the observations VentureOne reports for European firms, 76\% are one-year-ahead forecasts (U.S. is $52 \%$ ), $13 \%$ are two-year-ahead forecasts (U.S. is $19 \%$ ), and only $11 \%$ are span three-, four-, or five-yearahead horizons (U.S. is 29\%). A second distinction is that the European forecasts are heavily focused on 2001-2007, whereas U.S. forecasts have broad coverage over 1987-2007. Thus the results we present in this Appendix pertain only to one-year-ahead and two-year-ahead forecasts for European companies. It seems likely to suppose that more robust analysis will become possible only as substantially more years worth of data accumulates over the next decade.

Table B.1 compares U.S. and European management forecasts. European forecasts are limited here to those denominated in Euros (estimating separate models for each currency is infeasible given the limited data). We stress that the European results cover far fewer observations and are markedly more time-period specific. Taking $\$ 1$ as approximately $€ 1$ over the sample period, table B.1 suggests that European companies typically forecast lower revenues and expenses than do U.S. venture-backed firms. Consistent with the lower IRRs that European venture funds on average earn, untabulated results also show that European firms experience smaller revenue growth rates. Rosa and Raade (2006) report that during the period 1999-2003 (1994-2003), U.S. venture funds' mean IRR was 23\% (15\%) versus 2.3\% (8.3\%) for European venture funds. 
Table B.1

Descriptive statistics for historical vs. management forecasted revenues, expenses and net income

\begin{tabular}{|c|c|c|c|c|c|c|c|c|}
\hline \multirow[t]{2}{*}{ U.S. firms } & \multicolumn{2}{|c|}{ Revenues } & \multicolumn{3}{|c|}{ Expenses } & \multicolumn{3}{|c|}{ Net income } \\
\hline & \#obs. & Median Mean & \#obs. & Median & Mean & \#obs & Median & Mean \\
\hline All historical data & 6,890 & $\$ 5.9 \$ 22.3$ & 6,154 & $\$ 11.9$ & $\$ 28.2$ & 6,154 & $\$-2.4$ & $\$-5.1$ \\
\hline $\begin{array}{l}\text { Forecasts: } \\
\text { 1-year-ahead } \\
\text { 2-years-ahead }\end{array}$ & $\begin{array}{r}1,250 \\
463\end{array}$ & $\begin{array}{ll}\$ 5.3 & \$ 14.2 \\
\$ 11.9 & \$ 21.4\end{array}$ & $\begin{array}{l}621 \\
307\end{array}$ & $\begin{array}{ll}\$ & 7.6 \\
\$ & 2.8\end{array}$ & $\begin{array}{l}\$ 15.2 \\
\$ 21.8\end{array}$ & $\begin{array}{l}621 \\
307\end{array}$ & $\begin{array}{l}\$-1.1 \\
\$ 0.7\end{array}$ & $\begin{array}{l}\$-2.2 \\
\$ 1.4\end{array}$ \\
\hline
\end{tabular}

\begin{tabular}{|c|c|c|c|c|c|c|c|c|c|}
\hline \multirow[t]{2}{*}{ European firms } & \multicolumn{3}{|c|}{ Revenues } & \multicolumn{3}{|c|}{ Expenses } & \multicolumn{3}{|c|}{ Net income } \\
\hline & \#obs. & Median & Mean & \#obs. & Median & Mean & \#obs. & Median & Mean \\
\hline $\begin{array}{l}\text { All historical data } \\
\text { Forecasts: }\end{array}$ & 628 & $€ 3.8$ & $€ 9.0$ & 212 & $€ 3.9$ & $€ 8.9$ & 212 & $€ 0.0$ & $€-0.4$ \\
\hline 1-year-ahead & 195 & $€ 3.6$ & $€ 9.6$ & 63 & $€ 3.2$ & $€ 8.4$ & 63 & $€ 0.1$ & $€-0.2$ \\
\hline 2 -years-ahead & 35 & $€ 4.1$ & $€ 13.1$ & 15 & $€ 4.3$ & $€ 6.6$ & 15 & $€ 0.4$ & $€-0.2$ \\
\hline
\end{tabular}

Table B.2 reports the results of estimating European managers’ financial forecast biases. Subject to the caveat of small sample sizes, it appears that European managers exhibit slightly optimistic forecasts of profitability at one- and two-year-ahead horizons. However, the results are typically less statistically significant than with those obtained for U.S. data.

\section{Table B.2}

\section{Comparison of mean management percentage forecast errors for U.S. versus European private venture-backed firms}

The European data is limited to observations denominated in Euros. As with U.S. data, we estimate a separate model for actual historical data by industry sector. Results below are for all industry sector observations pooled together.

\begin{tabular}{l|rrr|rrr|rrr}
\hline & \multicolumn{4}{c}{ Revenues } & \multicolumn{3}{c}{ Expenses } & \multicolumn{3}{c}{ Profitability } \\
\hline U.S. firms & \# obs. & Mean & t-stat. & \# obs. & Mean & t-stat. & \# obs. & Mean & t-stat. \\
\hline 1-year-ahead & 1,242 & $-11 \%$ & $(-2.6)$ & 619 & $-28 \%$ & $(-6.0)$ & 617 & $35 \%$ & $(10.6)$ \\
2-years-ahead & 459 & $42 \%$ & $(4.2)$ & 306 & $-5 \%$ & $(-0.8)$ & 303 & $64 \%$ & $(6.2)$ \\
\hline European firms & \# obs. & Mean & t-stat. & \# obs. & Mean & t-stat. & \# obs. & Mean & t-stat. \\
\hline 1-year-ahead & 186 & $5 \%$ & $(0.5)$ & 59 & $-3 \%$ & $(0.1)$ & 59 & $8 \%$ & $(3.3)$ \\
2-years-ahead & 35 & $30 \%$ & $(0.7)$ & 14 & $22 \%$ & $(0.3)$ & 15 & $7 \%$ & $(3.4)$ \\
\hline
\end{tabular}


Figure 1

Illustrative example of the type of data in VentureOne's financial forecast database

\begin{tabular}{|c|c|c|c|c|c|}
\hline $\begin{array}{c}\text { Firm's } \\
\text { EntityID }\end{array}$ & $\begin{array}{c}\text { Firm's } \\
\text { Fiscal Year }\end{array}$ & $\begin{array}{l}\text { REV } \\
\text { (\$mil) }\end{array}$ & $\begin{array}{c}\mathrm{NI} \\
(\$ \mathrm{mil})\end{array}$ & $\begin{array}{c}\text { Implied } \\
\text { EXP (\$mil) }\end{array}$ & DataType \\
\hline 4 & 1992 & 6 & -1.2 & 7.2 & Actual \\
\hline 9 & 1994 & 0.15 & -0.72 & 0.87 & Actual \\
\hline 9 & 1995 & 1.27 & -1.5 & 2.77 & Actual \\
\hline 9 & 1996 & 7.14 & -5.6 & 12.74 & Actual \\
\hline 13 & & 10 & & & Estimated \\
\hline 13 & 1985 & 1.7 & & & Actual \\
\hline 13 & 1986 & & 2 & & Actual \\
\hline 13 & 1987 & 10 & 0.2 & 9.8 & Actual \\
\hline 13 & 1988 & 14 & -1.6 & 15.6 & Forecast \\
\hline 13 & 1989 & 17 & 0.1 & 16.9 & Forecast \\
\hline 13 & 1990 & 25 & 2.4 & 22.6 & Forecast \\
\hline 13 & 1991 & 40 & 6 & 34 & Forecast \\
\hline 26 & 2001 & 130 & 28 & 102 & Forecast \\
\hline 26 & 2002 & 170 & 45 & 125 & Forecast \\
\hline
\end{tabular}

- Missing data are coded as “.”

- $\quad$ Firm’s EntityID = firm identifier.

- $\quad$ Firm's Fiscal Year = yyyy only (the mmdd component is not known).

- Implied EXP = REV - NI when both REV and NI are not missing.

- DataType

o Actual = actual historical amount. S-1 filings are the source for many, but not all, of the "Actual” figures. If press releases or other secondary sources have very specific information, VentureOne codes it as "Actual."

o Estimated = typically for past or current time periods. Numbers are usually derived from secondary sources (such as press releases, VentureWire, the Wall Street Journal, Business Week, etc.) and, in the judgment of VentureOne's research staff, are not specific enough to classify as “Actual.” For example, the secondary source may say that revenues are "in the \$300-\$500 mil range" so VentureOne would enter \$400 mil. We exclude "Estimated" observations.

o $\quad$ Forecast $=$ forecast made by company management. "Forecast" numbers also frequently come from secondary sources and simply indicate that the company's managers expect to generate a certain amount of revenue or net income but has not actually done so yet. Such numbers can be changed to "Actual” if VentureOne gets actual information later. 


\section{Figure 2}

Median historical vs. management forecasted real revenues, real expenses and real net income in \$ millions, by firm age (Private venture-backed U.S. firms, 1985-2005)

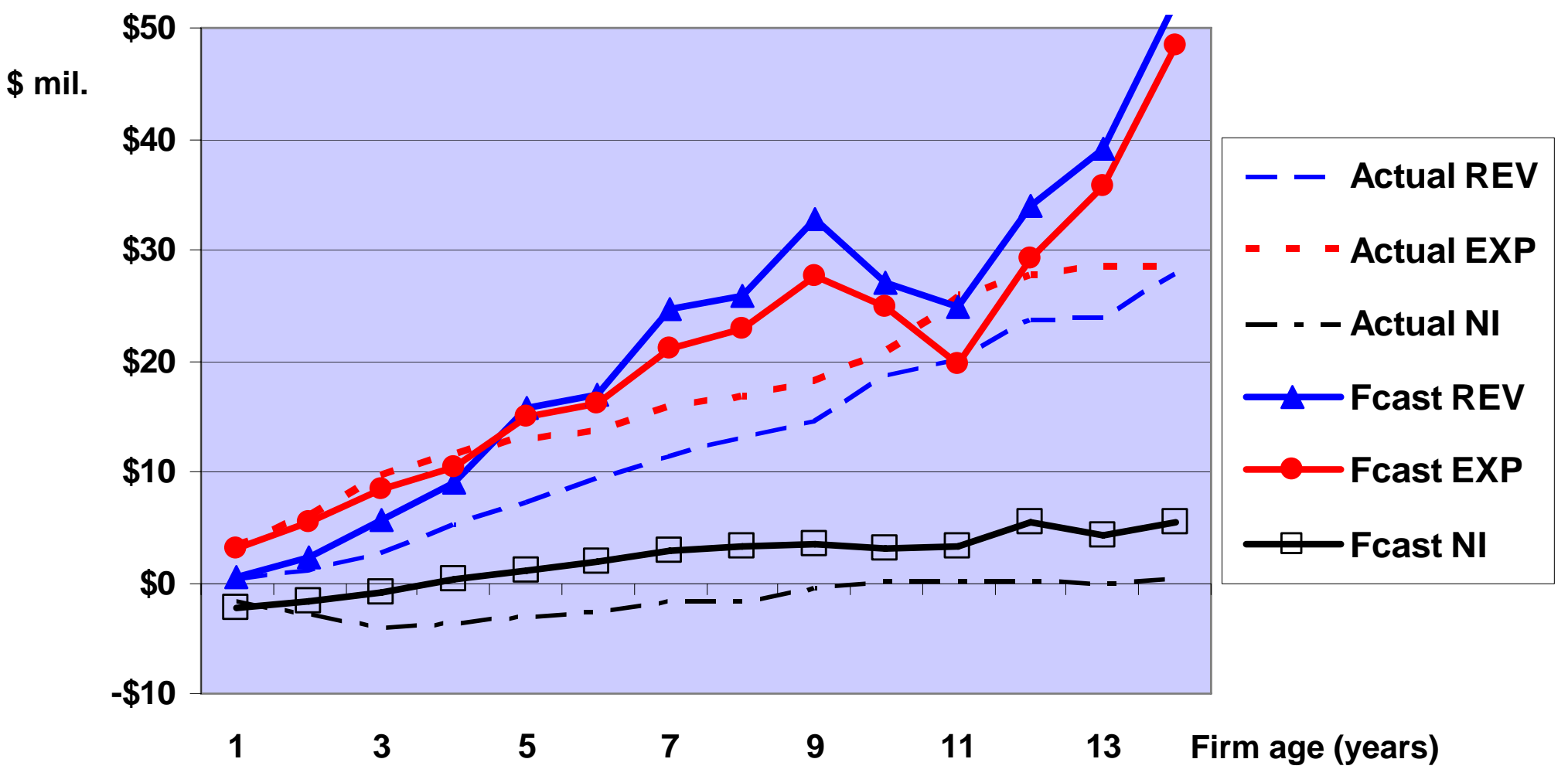

Notes: All financial statement variables are in real terms (using the CPI pivot point of June 2005). The data are restricted to those firm-year observations for which both revenues and net income were available. 


\section{Figure 3}

Distribution of percentage forecast errors in managers' revenue, expense and profitability predictions, by forecast horizon (Private venture-backed U.S. firms, 1985-2007)

Panel A: Mean percent forecast errors

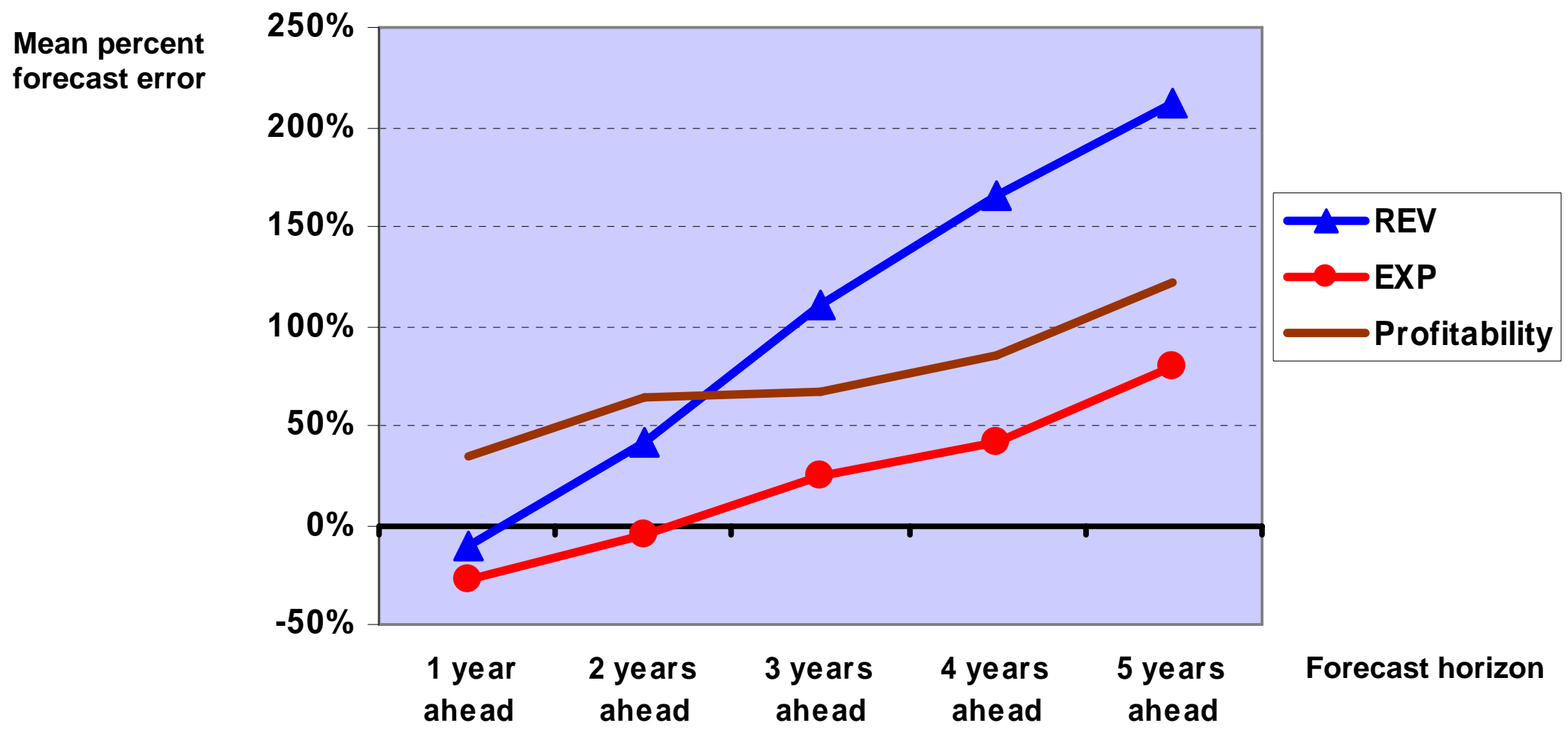

Note: Profitability is defined as net income scaled by revenue. The methods by which forecast errors are computed are detailed in section 3.1 of the text. 


\section{Figure 3 (continued)}

Panel B: Key percentiles of forecast error distributions
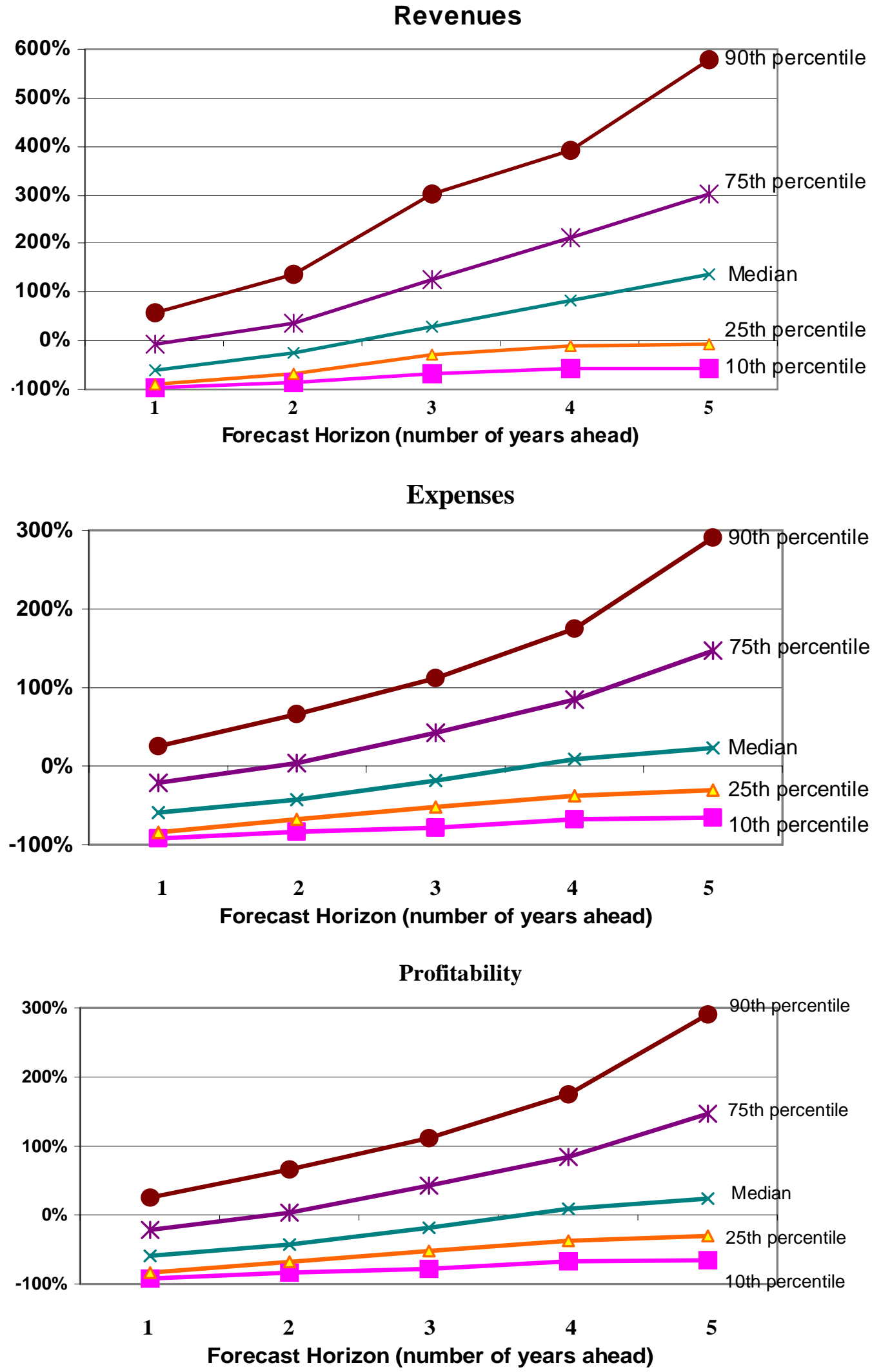


\section{Table 1}

Selection criteria applied to VentureOne's financial database to obtain firm-year observations that could be used to estimate the degree of bias in managers' forecasts of one- through five-year-ahead revenues, expenses and profitability

Less: $\quad$ Observations where:

Firm's founding date or industry classification or state location were missing

Firm is more than 15 years old in year the forecast is for 4,171

Fiscal year was missing, before 1985, or after 2007

Revenues were datatype = "Estimated"

Observation was a forecast for six or more years ahead

Extreme outliers

$=\quad$ Firm-year revenue observations for private venture-backed U.S. companies

Of which: Number of observations where datatype = "Actual"

Number of observations where datatype $=$ "Forecast"

Note 1: Extreme outliers were identified from scatterplots of revenues against firm age. Most outliers arise from miscodings of firm age (e.g., from a firm ten years old changing its name but then one year later being coded as being a one year old firm).

Note 2: All firm-year revenue observations do not have an associated expense number (see table 3), 


\section{Table 2}

\section{Descriptive statistics on general characteristics of firms in VentureOne's forecast database}

The sample is the set of private venture-backed U.S. firms in VentureOne's financial forecast database that satisfy the selection criteria detailed in table 1.

Panel A: Descriptive statistics on firm age (in years)

Type of data \# obs. Mean Stdev. Min. Q1 Median Q3 Max.

Historical (actual)

6,890

$5.2 \quad 3.2$

0.1

2.7

4.4

$\begin{array}{ll}7.0 & 15\end{array}$

Management forecasts

2,386

$5.6 \quad 2.8$

0.

3.5

$5.2 \quad 7.2$

Panel B: Descriptive statistics on VentureOne industry sectors, and firm headquarters

\begin{tabular}{lrlr} 
VentureOne industry sector & \# obs. & Headquarter state & \# obs. \\
\hline Healthcare/Biotech & $2,552(28 \%)$ & California & 3,719 \\
Information Technology & $4,916(53 \%)$ & Massachusetts & 1,056 \\
Retail \& Cons/Bus Prod/Serv & $1,517(16 \%)$ & Texas & 450 \\
Other & $\underline{291(3 \%)}$ & New York & 322 \\
& $\underline{9,276(100 \%)}$ & Other states & $\underline{3,729}$ \\
& & & $\underline{9,276}$
\end{tabular}

Panel C: Distribution of number of historical and forecasted revenues by calendar time

\begin{tabular}{c|c|ccccc}
\multicolumn{1}{c}{$\begin{array}{c}\text { Historical } \\
\text { data }\end{array}$} & $\begin{array}{c}\text { 1 year } \\
\text { ahead } \\
\text { forecast }\end{array}$ & $\begin{array}{c}\text { 2 years } \\
\text { ahead } \\
\text { forecast }\end{array}$ & $\begin{array}{c}\text { 3 years } \\
\text { ahead } \\
\text { forecast }\end{array}$ & $\begin{array}{c}\text { 4 years } \\
\text { ahead } \\
\text { forecast }\end{array}$ & $\begin{array}{c}5 \text { years } \\
\text { ahead } \\
\text { forecast }\end{array}$ \\
\hline $1985-86$ & 59 & 5 & 1 & 0 & 0 & 0 \\
$1987-88$ & 247 & 20 & 11 & 4 & 1 & 0 \\
$1989-90$ & 735 & 26 & 9 & 14 & 7 & 2 \\
$1991-92$ & 1,077 & 65 & 37 & 15 & 7 & 4 \\
$1993-94$ & 958 & 79 & 75 & 52 & 29 & 9 \\
$1995-96$ & 962 & 88 & 55 & 65 & 58 & 26 \\
$1997-98$ & 1,102 & 153 & 80 & 65 & 39 & 40 \\
$1999-00$ & 746 & 208 & 53 & 31 & 44 & 35 \\
$2001-02$ & 632 & 377 & 61 & 24 & 14 & 7 \\
$2003-04$ & 372 & 189 & 68 & 28 & 14 & 9 \\
$2005-07$ & 0 & 40 & 13 & 13 & 10 & 9 \\
\hline $1985-07$ & 6,890 & 1,250 & 463 & 311 & 223 & 139 \\
\hline $1985-07$ & $100 \%$ & $52 \%$ & $20 \%$ & $13 \%$ & $9 \%$ & $6 \%$ \\
\hline
\end{tabular}

Note: Forecasts are classified based on the year the forecast applies to, not the year in which the forecast is made. 
Table 3

\section{Descriptive statistics for historical vs. management forecasted revenues, expenses and net income}

The sample is the set of private venture-backed U.S. firms in VentureOne's financial statement database that satisfy the selection criteria detailed in table 1. All financial statement variables are in real terms (using the CPI pivot point of June 2005). Annual growth rates for forecasts beyond one-year-ahead are defined using year-to-year increases in forecasts.

Panel A:

Revenues

Expenses

Net income

\begin{tabular}{l|rrr|rrr|rrr} 
& \multicolumn{2}{c}{ \#obs. Median } & Mean & \#obs. Median & Mean & \multicolumn{2}{c}{ \#obs. Median } & Mean \\
\hline All historical data & 6,890 & $\$ 5.9$ & $\$ 22.3$ & 6,154 & $\$ 11.9$ & $\$ 28.2$ & 6,154 & $\$-2.4$ & $\$-5.1$ \\
\hline Forecasts: & & & & & & & & & \\
1-year-ahead & 1,250 & 5.3 & 14.2 & 621 & 7.6 & 15.2 & 621 & -1.1 & -2.2 \\
2-years-ahead & 463 & 11.9 & 21.4 & 307 & 12.8 & 21.8 & 307 & 0.7 & 1.4 \\
3-years-ahead & 311 & 25.9 & 37.5 & 245 & 21.7 & 31.5 & 245 & 3.6 & 5.3 \\
4-years-ahead & 223 & 43.6 & 56.5 & 190 & 32.2 & 43.1 & 190 & 6.9 & 10.2 \\
5-years-ahead & 139 & 61.0 & 76.0 & 123 & 49.6 & 59.8 & 123 & 10.4 & 15.3 \\
\hline
\end{tabular}

Panel B:

Annual growth rate in revenues, by key percentiles

\begin{tabular}{l|r|rrrrr}
\cline { 2 - 7 } & \multicolumn{1}{c}{ \#obs. } & $10^{\text {th }}$ & $25^{\text {th }}$ & $50^{\text {th }}$ & $75^{\text {th }}$ & $90^{\text {th }}$ \\
\hline All historical data & 4,143 & $-5 \%$ & $8 \%$ & $48 \%$ & $143 \%$ & $418 \%$ \\
\hline 1-year-ahead forecasts & 389 & $7 \%$ & $46 \%$ & $112 \%$ & $246 \%$ & $660 \%$ \\
2-year-ahead forecasts & 422 & $29 \%$ & $72 \%$ & $164 \%$ & $384 \%$ & $951 \%$ \\
3-year-ahead forecasts & 292 & $40 \%$ & $71 \%$ & $111 \%$ & $169 \%$ & $299 \%$ \\
4-year-ahead forecasts & 215 & $29 \%$ & $49 \%$ & $77 \%$ & $112 \%$ & $176 \%$ \\
5-year-ahead forecasts & 138 & $19 \%$ & $37 \%$ & $57 \%$ & $88 \%$ & $113 \%$ \\
\hline
\end{tabular}

Panel C:

Annual growth rate in expenses, by key percentiles

\begin{tabular}{l|r|rrrrr}
\cline { 2 - 6 } & \#obs. & $10^{\text {th }}$ & $25^{\text {th }}$ & $50^{\text {th }}$ & $75^{\text {th }}$ & $90^{\text {th }}$ \\
\hline All historical data & 4,081 & $-4 \%$ & $16 \%$ & $48 \%$ & $114 \%$ & $248 \%$ \\
\hline 1-year-ahead forecasts & 229 & $-6 \%$ & $17 \%$ & $52 \%$ & $109 \%$ & $226 \%$ \\
2-year-ahead forecasts & 264 & $15 \%$ & $36 \%$ & $78 \%$ & $143 \%$ & $268 \%$ \\
3-year-ahead forecasts & 226 & $26 \%$ & $47 \%$ & $81 \%$ & $112 \%$ & $151 \%$ \\
4-year-ahead forecasts & 181 & $22 \%$ & $40 \%$ & $62 \%$ & $89 \%$ & $119 \%$ \\
5-year-ahead forecasts & 122 & $17 \%$ & $32 \%$ & $56 \%$ & $79 \%$ & $106 \%$ \\
\hline
\end{tabular}

Panel D:

Net income-to-expense ratio, by key percentiles

\begin{tabular}{l|r|rrrrr}
\cline { 2 - 7 } & \#obs. & $10^{\text {th }}$ & $25^{\text {th }}$ & $50^{\text {th }}$ & $7^{\text {th }}$ & $90^{\text {th }}$ \\
\hline All historical data & 6,143 & $-100 \%$ & $-84 \%$ & $-34 \%$ & $0 \%$ & $8 \%$ \\
\hline 1-year-ahead forecasts & 610 & $-89 \%$ & $-60 \%$ & $-20 \%$ & $4 \%$ & $16 \%$ \\
2-year-ahead forecasts & 306 & $-55 \%$ & $-16 \%$ & $6 \%$ & $15 \%$ & $26 \%$ \\
3-year-ahead forecasts & 245 & $0 \%$ & $9 \%$ & $16 \%$ & $26 \%$ & $48 \%$ \\
4-year-ahead forecasts & 190 & $7 \%$ & $13 \%$ & $20 \%$ & $34 \%$ & $55 \%$ \\
5-year-ahead forecasts & 123 & $9 \%$ & $13 \%$ & $21 \%$ & $33 \%$ & $54 \%$ \\
\hline
\end{tabular}




\section{Table 3 (continued)}

Panel E: Regressions of historical profitability measures on industry sector and firm age

The data exclude firm-year observations in the industry sector classified by VentureOne as "Other." All regressions are estimated without an intercept. However, the adjusted $\mathrm{R}^{2}$ statistics are taken from equivalent regressions that do include an intercept, but excludes one of the dummy variables. Given the directional nature of the predictions made regarding the relative sizes of coefficients on the industry dummies, the p-values reported in the bottom part of the table are one-tailed. Two-tailed p-values are shown in [.], while t-statistics are shown in (.).

Econometric method applied

\begin{tabular}{|c|c|}
\hline Logistic & OLS \\
\hline \multicolumn{2}{|c|}{ Dependent variable } \\
\hline $\begin{array}{l}\text { Dummy set to one } \\
\text { if net income }>0\end{array}$ & $\begin{array}{c}\text { Ratio of net income } \\
\text { to expenses }\end{array}$ \\
\hline $\begin{array}{c}-2.93 \\
{[<0.0001]}\end{array}$ & $\begin{array}{c}-0.83 \\
(-70.3)\end{array}$ \\
\hline $\begin{array}{c}-2.20 \\
{[<0.0001]}\end{array}$ & $\begin{array}{r}-0.60 \\
(-55.3)\end{array}$ \\
\hline $\begin{array}{c}-1.81 \\
{[<0.0001]}\end{array}$ & $\begin{array}{r}-0.48 \\
(-32.6)\end{array}$ \\
\hline $\begin{array}{c}0.22 \\
{[<0.0001]}\end{array}$ & $\begin{array}{r}0.05 \\
(32.2)\end{array}$ \\
\hline 5,977 & 5,966 \\
\hline $\begin{array}{l}0.12 \\
73 \%\end{array}$ & $\begin{array}{c}0.22 \\
\text { n.app. }\end{array}$ \\
\hline $\begin{array}{l}<0.0001 \\
<0.0001 \\
<0.0001\end{array}$ & $\begin{array}{l}<0.0001 \\
<0.0001 \\
<0.0001\end{array}$ \\
\hline
\end{tabular}




\section{Table 4}

\section{OLS regressions of historical and management forecasted revenues, expenses and net income on proposed determinants (Private venture-backed U.S. firms, 1985-2007)}

The samples are all venture-backed private firms in VentureOne’s U.S. financial statement database satisfying the selection criteria described in table 1. All figures reported are the means of the output obtained from estimating the underlying regression equation separately for each of VentureOne's four industry sectors (Healthcare/Biotech; Information Technology; Retail \& Cons/Bus Prod/Serv; and Other). Revenues, expenses and net income are in real terms using the CPI pivot point of June 2005. Intercepts and four state dummies (CA, MA, NY, TX) are estimated but for parsimony their parameter estimates are not reported. Mean t-statistics are in parentheses.

Panel A: Historical revenues, expenses and net income (1985-2004)

\begin{tabular}{l|rr|rr|rr} 
& \multicolumn{9}{c}{ Dependent variable } \\
\cline { 2 - 7 } Determinants: & \multicolumn{2}{c}{ Revenues } & \multicolumn{2}{c}{ Expenses } & Net Income \\
\hline Firm age & 2.59 & -0.40 & 2.41 & -0.59 & 0.27 & 0.34 \\
& $(5.8)$ & $(-1.9)$ & $(4.7)$ & $(-2.3)$ & $(3.1)$ & $(3.6)$ \\
Positive[dep. variable] & & 1.18 & & 1.13 & & 1.28 \\
$\quad$ lagged one year & & $(76.2)$ & & $(64.4)$ & $(10.4)$ \\
Negative[dep. variable] & & & & & & 0.64 \\
$\quad$ lagged one year & & & & & $0.4)$ \\
\hline Mean adj. R & & & & & 0.03 & 0.40 \\
Mean \# obs. per regression & 1,723 & 1,103 & 1,539 & 1,021 & 1,539 & 1,021 \\
\hline
\end{tabular}

Panel B: Forecasted revenues, expenses and net income (1985-2007)

Dependent variable

\begin{tabular}{l|rr|rr|rc}
\cline { 2 - 6 } Determinants: & \multicolumn{2}{c}{ Revenues } & \multicolumn{2}{c}{ Expenses } & \multicolumn{2}{c}{ Net Income } \\
\hline Firm age & 3.70 & 0.14 & 3.07 & 0.07 & 1.14 & 0.05 \\
& $(6.7)$ & $(0.0)$ & $(4.9)$ & $(-0.1)$ & $(4.9)$ & $(0.6)$ \\
Positive[dep. variable] & & 1.45 & & 1.39 & & 1.56 \\
$\quad$ lagged one year & & $(39.4)$ & & $(35.9)$ & & $(15.3)$ \\
Negative[dep. variable] & & & & & & 0.54 \\
lagged one year & & & & & & $(3.0)$ \\
\hline Mean adj. R & & & & & 0.06 & 0.61 \\
Mean \# obs. per regression & 597 & 371 & 372 & 256 & 372 & 256 \\
\hline
\end{tabular}




\section{Table 5}

\section{Mean percentage management forecast errors for revenues, expenses and profitability, by forecasting horizon (Private venture-backed U.S. firms, 1985-2007)}

The samples are the venture-backed private firms in VentureOne's U.S. financial statement database that satisfy the selection criteria detailed in table 1. T-statistics are in parentheses. Forecasts are denoted as "1 year ahead”, "2 years ahead”, etc.

As described in detail in section 3.1 of the main text, revenue (expense) forecast errors are defined as the difference between managers' revenue (expense) forecasts and historicallygrounded conditional projections of revenues (expenses), deflated by the latter. Profitability forecast errors are defined as managers' net income forecasts less historically-grounded conditional projections of net income, scaled by historically-grounded conditional projections of revenues, where historically-grounded conditional projections of net income is the difference between historically-grounded conditional projections of revenues and expenses.

In the minority of cases where the historically-grounded conditional projection of revenue is negative, no forecast error is computed; likewise for expenses. If a forecast error exceeds $2,500 \%$ then the forecast error is excluded in computing the mean forecast error.

The mean forecast error for revenues and expenses is a weighted average, where the weights are the inverse of the standard errors of the predicted revenues. The t-statistics shown in parentheses for revenues and expenses are also computed using these same weights. For profitability forecast errors, simple (i.e., unweighted) mean forecast errors and t-statistics are computed.

Results for the industry sector classified by VentureOne as “Other” are not separately tabulated due to relatively small numbers of observations, particularly at longer forecasting horizons.

Panel A: All industry sectors pooled

\begin{tabular}{l|rrr|rrr|rrr}
\multicolumn{4}{c}{} & \multicolumn{4}{c}{ Revenues } & \multicolumn{3}{c}{ Expenses } & \multicolumn{3}{c}{ Profitability } \\
\hline & \# obs. & Mean & t-stat. & \# obs. & Mean & t-stat. & \# obs. & Mean & t-stat. \\
\hline Historical data & 6,811 & $-3 \%$ & $(-1.2)$ & 6,149 & $-1 \%$ & $(-0.5)$ & 6,082 & $5 \%$ & $(2.4)$ \\
\hline 1 year ahead & 1,242 & $-11 \%$ & $(-2.6)$ & 619 & $-28 \%$ & $(-6.0)$ & 617 & $35 \%$ & $(10.6)$ \\
2 years ahead & 459 & $42 \%$ & $(4.2)$ & 306 & $-5 \%$ & $(-0.8)$ & 303 & $64 \%$ & $(6.2)$ \\
3 years ahead & 305 & $111 \%$ & $(7.1)$ & 244 & $25 \%$ & $(2.5)$ & 239 & $67 \%$ & $(12.0)$ \\
4 years ahead & 218 & $165 \%$ & $(8.4)$ & 189 & $41 \%$ & $(4.8)$ & 186 & $85 \%$ & $(9.7)$ \\
5 years ahead & 134 & $212 \%$ & $(7.6)$ & 123 & $80 \%$ & $(5.7)$ & 121 & $122 \%$ & $(5.6)$ \\
\hline
\end{tabular}




\section{Table 5 (continued)}

Panel B: Healthcare/Biotech sector only

Healthcare/Biotech

\begin{tabular}{l|rrr|rrr|rrr}
\cline { 2 - 11 } & \multicolumn{4}{c}{ Revenues } & \multicolumn{4}{c}{ Expenses } & \multicolumn{3}{c}{ Profitability } \\
\hline & \# obs. & Mean & t-stat. & \# obs. & Mean & t-stat. & \# obs. & Mean & t-stat. \\
\hline Historical data & 1,967 & $-3 \%$ & $(-0.5)$ & 1,891 & $-2 \%$ & $(-0.4)$ & 1,827 & $8 \%$ & $(1.1)$ \\
\hline 1 year ahead & 243 & $49 \%$ & $(2.9)$ & 149 & $-12 \%$ & $(-1.6)$ & 148 & $63 \%$ & $(5.9)$ \\
2 years ahead & 98 & $114 \%$ & $(3.7)$ & 76 & $32 \%$ & $(1.7)$ & 74 & $88 \%$ & $(4.4)$ \\
3 years ahead & 63 & $204 \%$ & $(3.9)$ & 56 & $65 \%$ & $(2.2)$ & 53 & $113 \%$ & $(5.2)$ \\
4 years ahead & 54 & $278 \%$ & $(4.7)$ & 51 & $56 \%$ & $(3.0)$ & 49 & $150 \%$ & $(5.1)$ \\
5 years ahead & 41 & $305 \%$ & $(4.8)$ & 37 & $106 \%$ & $(3.9)$ & 36 & $238 \%$ & $(3.5)$ \\
\hline
\end{tabular}

Panel C: Information Technology sector only

Information Technology

\begin{tabular}{l|rrr|rrr|rrr}
\cline { 2 - 10 } & \multicolumn{3}{c}{ Revenues } & \multicolumn{3}{c}{ Expenses } & \multicolumn{3}{c}{ Profitability } \\
\hline & \# obs. & Mean & t-stat. & \# obs. & Mean & t-stat. & \# obs. & Mean & t-stat. \\
\hline Historical data & 3,544 & $-3 \%$ & $(-1.1)$ & 3,126 & $-1 \%$ & $(-0.3)$ & 3,126 & $3 \%$ & $(2.2)$ \\
\hline 1 year ahead & 717 & $-27 \%$ & $(-7.7)$ & 332 & $-30 \%$ & $(-4.0)$ & 332 & $26 \%$ & $(3.4)$ \\
2 years ahead & 274 & $28 \%$ & $(2.5)$ & 172 & $-13 \%$ & $(-1.9)$ & 172 & $55 \%$ & $(5.5)$ \\
3 years ahead & 185 & $95 \%$ & $(6.7)$ & 141 & $19 \%$ & $(1.9)$ & 141 & $62 \%$ & $(16.7)$ \\
4 years ahead & 118 & $142 \%$ & $(7.5)$ & 97 & $47 \%$ & $(4.2)$ & 97 & $67 \%$ & $(13.7)$ \\
5 years ahead & 65 & $204 \%$ & $(5.8)$ & 58 & $88 \%$ & $(4.3)$ & 58 & $85 \%$ & $(9.0)$ \\
\hline
\end{tabular}

Panel D: Retail \& Consumer/Business Products/Services sector only

Retail \& Consumer/Business Products/Services

\begin{tabular}{l|rrr|rrr|rrr}
\cline { 2 - 10 } & \multicolumn{4}{c}{ Revenues } & \multicolumn{3}{c}{ Expenses } & \multicolumn{3}{c}{ Profitability } \\
\hline & \# obs. & Mean & t-stat. & \# obs. & Mean & t-stat. & \# obs. & Mean & t-stat. \\
\hline Historical data & 1,097 & $-2 \%$ & $(-0.4)$ & 958 & $-1 \%$ & $(-0.3)$ & 958 & $8 \%$ & $(5.9)$ \\
\hline 1 year ahead & 253 & $-41 \%$ & $(-7.4)$ & 122 & $-54 \%$ & $(-13.2)$ & 122 & $24 \%$ & $(4.6)$ \\
2 years ahead & 71 & $-47 \%$ & $(-7.0)$ & 44 & $-59 \%$ & $(-10.1)$ & 44 & $22 \%$ & $(6.4)$ \\
3 years ahead & 42 & $-22 \%$ & $(-2.0)$ & 35 & $-49 \%$ & $(-6.9)$ & 35 & $28 \%$ & $(8.7)$ \\
4 years ahead & 34 & $26 \%$ & $(1.2)$ & 30 & $-32 \%$ & $(-3.3)$ & 30 & $47 \%$ & $(6.5)$ \\
5 years ahead & 20 & $3 \%$ & $(0.1)$ & 19 & $-33 \%$ & $(-2.0)$ & 19 & $46 \%$ & $(5.0)$ \\
\hline
\end{tabular}




\section{Table 6}

\section{Regressions of management forecast errors in table 5 on industry sector dummies, forecasting horizon, firm age, and headquarter state dummies \\ (Private venture-backed U.S. firms, 1985-2007)}

All regressions are estimated without an intercept. However, the adjusted $\mathrm{R}^{2}$ statistics are taken from equivalent regressions that do include an intercept, but excludes one of the dummy variables. Given the directional nature of the predictions made regarding the relative sizes of coefficients on the industry dummies, the p-values reported in the bottom part of the table are one-tailed.

Dependent variable

Percentage forecast error for:

\begin{tabular}{|c|c|c|c|c|c|c|}
\hline Determinants: & Revt & enues & Expen & ses & Profi & ability \\
\hline $\begin{array}{l}\text { Healthcare/Biotech dummy } \\
\text { (HB) }\end{array}$ & $\begin{array}{c}7 \% \\
(0.6)\end{array}$ & $\begin{array}{l}-18 \% \\
(-1.2)\end{array}$ & $\begin{array}{l}-29 \% \\
(-3.3)\end{array}$ & $\begin{array}{l}-35 \% \\
(-3.2)\end{array}$ & $\begin{array}{l}61 \% \\
(6.5)\end{array}$ & $\begin{array}{l}54 \% \\
(4.6)\end{array}$ \\
\hline $\begin{array}{l}\text { Info. Tech. dummy } \\
\text { (IT) }\end{array}$ & $\begin{array}{l}-83 \% \\
(-9.5)\end{array}$ & $\begin{array}{r}-110 \% \\
(-8.7)\end{array}$ & $\begin{array}{l}-56 \% \\
(-8.0)\end{array}$ & $\begin{array}{l}-64 \% \\
(-6.6)\end{array}$ & $\begin{array}{c}5 \% \\
(0.7)\end{array}$ & $\begin{array}{l}-3 \% \\
(-0.3)\end{array}$ \\
\hline $\begin{array}{l}\text { Retail \& Cons/Bus dummy } \\
\text { (RCB) }\end{array}$ & $\begin{array}{r}-137 \% \\
(-8.9)\end{array}$ & $\begin{array}{r}-161 \% \\
(-9.2)\end{array}$ & $\begin{array}{r}-104 \% \\
(-8.7)\end{array}$ & $\begin{array}{r}-112 \% \\
(-8.4)\end{array}$ & $\begin{array}{l}-12 \% \\
(-1.2)\end{array}$ & $\begin{array}{l}-20 \% \\
(-1.6)\end{array}$ \\
\hline $\begin{array}{l}\text { Forecast horizon } \\
\text { [no. of years ahead] }\end{array}$ & $\begin{array}{c}57 \% \\
(16.2)\end{array}$ & $\begin{array}{c}54 \% \\
(13.9)\end{array}$ & $\begin{array}{c}26 \% \\
(10.1)\end{array}$ & $\begin{array}{l}25 \% \\
(8.8)\end{array}$ & $\begin{array}{l}19 \% \\
(7.2)\end{array}$ & $\begin{array}{l}18 \% \\
(6.0)\end{array}$ \\
\hline Firm age & & $\begin{array}{c}2.3 \\
(1.6)\end{array}$ & & $\begin{array}{c}0.3 \\
(0.2)\end{array}$ & & $\begin{array}{c}0.8 \\
(0.6)\end{array}$ \\
\hline CA headquarter dummy & & $\begin{array}{l}40 \% \\
(4.2)\end{array}$ & & $\begin{array}{l}29 \% \\
(4.0)\end{array}$ & & $\begin{array}{l}14 \% \\
(1.7)\end{array}$ \\
\hline MA headquarter dummy & & $\begin{array}{l}18 \% \\
(1.2)\end{array}$ & & $\begin{array}{l}-17 \% \\
(-1.5)\end{array}$ & & $\begin{array}{c}1 \% \\
(0.1)\end{array}$ \\
\hline NY headquarter dummy & & $\begin{array}{l}13 \% \\
(0.5)\end{array}$ & & $\begin{array}{l}-43 \% \\
(-2.5)\end{array}$ & & $\begin{array}{c}8 \% \\
(0.4)\end{array}$ \\
\hline TX headquarter dummy & & $\begin{array}{c}-67 \% \\
(-3.1)\end{array}$ & & $\begin{array}{l}-35 \% \\
(-6.6)\end{array}$ & & $\begin{array}{l}-17 \% \\
(-0.9)\end{array}$ \\
\hline $\begin{array}{l}\text { Adj. } \mathrm{R}^{2} \\
\# \text { obs. }\end{array}$ & $\begin{array}{c}0.14 \\
2,278\end{array}$ & $\begin{array}{c}0.16 \\
2,278\end{array}$ & $\begin{array}{c}0.09 \\
1,419\end{array}$ & $\begin{array}{c}0.11 \\
1,419\end{array}$ & $\begin{array}{c}0.07 \\
1,410\end{array}$ & $\begin{array}{c}0.07 \\
1,410\end{array}$ \\
\hline $\begin{array}{l}\operatorname{Pr}>F\{\mathrm{HB}=\mathrm{IT}\} \\
\operatorname{Pr}>\mathrm{F}\{\mathrm{HB}=\mathrm{RCB}\} \\
\operatorname{Pr}>\mathrm{F}\{\mathrm{IT}=\mathrm{RCB}\}\end{array}$ & $\begin{array}{l}<0.0001 \\
<0.0001 \\
<0.001\end{array}$ & $\begin{array}{l}<0.0001 \\
<0.0001 \\
<0.001\end{array}$ & $\begin{array}{l}<0.001 \\
<0.0001 \\
<0.0001\end{array}$ & $\begin{array}{l}<0.0001 \\
<0.0001 \\
<0.0001\end{array}$ & $\begin{aligned}< & 0.0001 \\
< & 0.0001 \\
& 0.04\end{aligned}$ & $\begin{array}{c}<0.0001 \\
<0.0001 \\
0.04\end{array}$ \\
\hline
\end{tabular}

